OPEN ACCESS

Edited by:

Stephanie DeWitte-Orr

Wilfrid Laurier University, Canada

Reviewed by:

Jonathan P. Rast,

Emory University School of Medicine,

United States

Serge Morand,

Center for the National Scientific

Research (CNRS), France

*Correspondence:

Barbara A. Katzenback

barb.katzenback@uwaterloo.ca

Specialty section: This article was submitted to

Comparative Immunology,

a section of the journal

Frontiers in Immunology

Received: 31 October 2018 Accepted: 18 December 2018

Published: 14 January 2019

Citation:

Varga JFA, Bui-Marinos MP and Katzenback BA (2019) Frog Skin

Innate Immune Defences: Sensing

and Surviving Pathogens.

Front. Immunol. 9:3128.

doi: 10.3389/fimmu.2018.03128

\section{Frog Skin Innate Immune Defences: Sensing and Surviving Pathogens}

\author{
Joseph F. A. Varga, Maxwell P. Bui-Marinos and Barbara A. Katzenback* \\ Department of Biology, University of Waterloo, Waterloo, ON, Canada
}

Amphibian skin is a mucosal surface in direct and continuous contact with a microbially diverse and laden aquatic and/or terrestrial environment. As such, frog skin is an important innate immune organ and first line of defence against pathogens in the environment. Critical to the innate immune functions of frog skin are the maintenance of physical, chemical, cellular, and microbiological barriers and the complex network of interactions that occur across all the barriers. Despite the global decline in amphibian populations, largely as a result of emerging infectious diseases, we understand little regarding the cellular and molecular mechanisms that underlie the innate immune function of amphibian skin and defence against pathogens. In this review, we discuss the structure, cell composition and cellular junctions that contribute to the skin physical barrier, the antimicrobial peptide arsenal that, in part, comprises the chemical barrier, the pattern recognition receptors involved in recognizing pathogens and initiating innate immune responses in the skin, and the contribution of commensal microbes on the skin to pathogen defence. We briefly discuss the influence of environmental abiotic factors (natural and anthropogenic) and pathogens on the immunocompetency of frog skin defences. Although some aspects of frog innate immunity, such as antimicrobial peptides are well-studied; other components and how they contribute to the skin innate immune barrier, are lacking. Elucidating the complex network of interactions occurring at the interface of the frog's external and internal environments will yield insight into the crucial role amphibian skin plays in host defence and the environmental factors leading to compromised barrier integrity, disease, and host mortality.

\footnotetext{
Keywords: amphibian, anuran, epithelial cells, mucosal tissue, antimicrobial peptides (AMPs), pattern recognition receptors (PRRs), skin microbiome, skin immunology
}

\section{INTRODUCTION}

Nearly 8,000 amphibian species have been discovered to date ( $88 \%$ belonging to order Anura-frogs and toads) and approximately 150 new species are discovered each year (1). Collectively, frogs have evolved unique skin adaptations to live in aquatic and terrestrial environments $(2,3)$, while exhibiting common elements in their skin composition and structure (4-6). Skin is an integral interface between an organism's internal and external environment and undergoes routine exposure to a myriad of environmental factors, including pathogen challenge. Frog skin is no exception; it acts as a critical immune organ constituting a complex network of physical, chemical, immunological, and microbiological barriers to pathogen insult. Striking commonalities exist between frog, fish, and mammalian skin and exemplify the importance of endeavours in comparative vertebrate skin biology to address numerous research areas $(7,8)$. As a consequence of their reliance 
on terrestrial or aquatic habitats, or a combination thereof, amphibian skin is a sophisticated mucosal organ with specialized adaptations required to perform various critical physiological functions (e.g., ion transport, respiration, water uptake, etc.), while still maintaining a selective barrier to the external environment $(2,3,9)$. Other than the presence of a sophisticated glandular system, a miraculous feature of amphibian skin that sets frogs apart from other vertebrates is their ability to rapidly heal deep wounds which protrude through the dermal layers without scar formation, including complete regeneration of any glands affected by the injury (8). Despite extensive studies showing that amphibian skin is vital to survival, and apart from antimicrobial peptides (AMPs) $(10,11)$, relatively little focus has been placed on examining the role of frog skin epithelium to pathogen defence. This focus is paramount since mucosal epithelia are more prone to pathogen attack, such as that seen in mammalian lung and gut epithelium (12-15). With the rise of declining amphibian populations globally (16), wherein emerging infectious diseases such as frog virus-3 (FV3), the type species of the genus Ranavirus (family Iridoviridae), and the fungal pathogen Batrachochytrium dendrobatidis ( $B d)$ $(17,18)$ are believed to be the proximal cause $(19,20)$. It is therefore important to understand the interplay between frog skin, pathogens and contributing environmental factors.

\section{AMPHIBIAN SKIN-THE FIRST BARRIER OF DEFENCE}

Maintenance of amphibian skin integrity is important for overall frog health-both in terms of conducting essential physiological processes and for defence against invading pathogens. Depending on the species, amphibian skin contributes to water uptake, ion transport, respiration, heat transfer, camouflage, and predator deterrence (9). Yet frog skin is particularly vulnerable to cutaneous injury due to the relatively thin and permeable nature of the organ-characteristics necessary to support many of the aforementioned physiological processes. Thus, frog skin is an important first line of defence against harmful agents in the environment that may disrupt skin function and/or cause cutaneous or systemic diseases, leading to interruption of essential physiological functions and ultimately amphibian death.

\footnotetext{
Abbreviations: AMP, antimicrobial peptide; Bd, bactrachochytrium dendrobatidis; CCRs, chemokine receptors; CLRs, C-type-lectin like receptors; $\mathrm{CPF}$, caerulein precursor fragment; DAMPs, damage-associated molecular patterns; dsRNA, double stranded RNA; EGFR, epidermal growth factor receptor; EK, Eberth-Katschenko; FPLR1, formyl peptide receptor-like-1; FV3, frog virus 3; GLP-1, glucagon-like peptide 1; GPCR, G-protein coupled receptor; hBD, human beta defensin; HDP, host defence peptide; IC50, inhibitory concentration 50; LGP2, laboratory of genetics and physiology 2; LPS, lipopolysaccharide; MAMPs, microbe-associated molecular patterns; MDA5, melanoma differentiationassociated gene 5; MIC, minimum inhibitory concentration; NF- $\mathrm{B}$, nuclear factor kappa-beta; NLR, nucleotide-binding oligomerization domain- (NOD-) like receptor; NOD, nucleotide-binding oligomerization domain; $\mathrm{P} 2 \mathrm{X} 7$, purinergic receptors; PAMP, pathogen-associated molecular pattern; PGLa, peptide glycineleucine-amide; PRR, pattern recognition receptor; RIG-I, retinoic acid inducible gene-I; RLR, RIG-I-like receptor; STAT3, signal transducer and activator of transcription 3; TLR, TOLL-like receptor; TLR, TOLL-like receptor; XPF, xenopsin precursor fragments.
}

In addition to common innate immune elements, amphibians have evolved specialized features to enhance innate immune defences to protect the vulnerable skin barrier, including a glandular network beneath the skin surface that are capable of producing a plethora of antimicrobial and toxic substances, thus aiding in the defence against pathogens and predators (6). While much remains to be elucidated, the holism between amphibian skin, host physiology and immunity is apparent.

\section{Skin Layer Organization and Composition}

Frog skin is composed of epidermal and dermal layers, with each layer predominantly consisting of epithelial and fibroblastic cells, respectively. While mammalian epidermal strata layers are welldefined due to its thickness, frog epidermis is relatively thin and thus often limited to the stratum corneum (outermost layer), central stratum spinosum, and stratum germinativum (basal layer) (Figure 1) (7). Frog epidermis is composed of stratified squamous epithelium, wherein the stratum corneum is composed of a very thin layer of keratinized cells (Figure 1) (7,21). Cells in the epidermis of tadpoles are ciliated in most of the frog species studied and cilia regress leading up to metamorphosis. In general, this is characterized by a global loss of ciliated skin cells at Gosner stages 25-30 with the exception of the retention of cilia around the eye and nasal areas $(22,23)$. To date, there are no studies on the importance of the mucociliary epithelium in adult frogs. We presume the mucociliary function in amphibians is similar to that of other organisms, where the cilia play an important role in sweeping trapped microbes away from mucosal surfaces $(24,25)$. The stratum spinosum is composed of terminally differentiating cells, acting as an intermediate layer between the stratum corneum and the regenerative stratum germinativum layer (7). The stratum germinativum, which directly connects to the dermis, contains a mixture of cell types including epithelial cells, immune cells (described in the paragraph immediately below) and chromatophores that provide frogs with dynamic pigmentation patterns (26). The dermal layer can be divided into two distinct layers: the upper spongious dermis and lower compact dermis (Figure 1). The spongious dermal layer is composed of loose connective tissue, while the compact dermal layer is formed by a series of interweaving collagenous fibre bundles, with fibronectin situated between breaks in the collagenous layers (Figure 1) (27, 28). Fibroblastic cells, which produce collagenous fibres to form connective tissue, are integral in anchoring the epidermal and dermal layers to the hypodermis particularly through collagenous columns (Figure 1) (27). A unique feature to select, mainly terrestrial, adult amphibian dermis is the separation of spongious and compact dermis by the Eberth-Katschenko (EK) layer (Figure 1) (5). This noncellular layer is composed entirely of glycosaminoglycans and glycoconjugates, wherein hyaluronan and dermatan sulphate have been reported as key constituents in various species $(29,30)$. Hyaluronan and other hyaluronan-like molecules in the EK layers are predominantly found on the dorsal side of amphibian skin. Hyaluronan molecules are proposed to reduce water evaporation thereby aiding in the prevention of desiccation, particularly in basking amphibians, since the molecules are highly water retentive (30). In addition to the EK divide, thick 


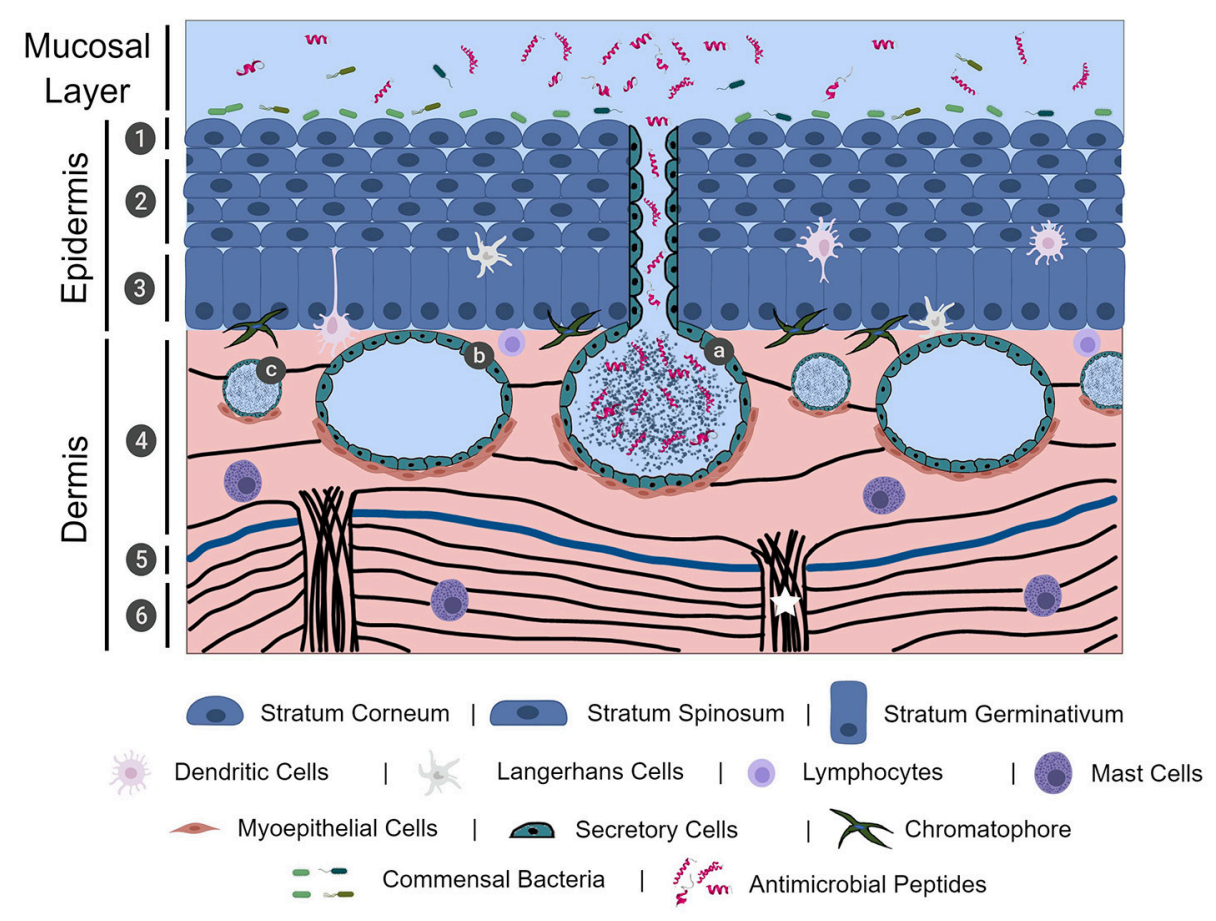

FIGURE 1 | The physical, chemical, cellular, and microbiological innate immune barriers of frog skin. Frog skin, which is mucosal in nature, contains physical, chemical, cellular, and microbiological barriers that work together in defence against pathogen assault. Frog skin is composed of an epidermal and dermal layer, containing resident immune cells throughout the layers. The epidermis is comprised of stratified squamous epithelial cells in three distinct layers: the stratum corneum (1), stratum spinosum (2), and stratum germinativum. The dermis is largely comprised of connective tissue formed by collagenous fibres (black lines) in two layers, the spongious dermis (4) and the compact dermis (6), connected by collagenous columns (white star). In mainly terrestrial frogs, the Eberth-Kastschenko layer (5, thick blue line) separates the spongious dermal layer and compact dermal layer. Glands within the dermal layer include granular glands (a), mucosal glands (b), and small mixed glands (c) that secrete a slew of compounds, including mucus and antimicrobial peptides. Commensal bacteria overlay the frog skin layers, forming the microbiological barrier. The image was, in part, created with the aid of BioRender.

collagenous columns extend upwards from the hypodermis to the spongious dermis layer, without impacting the compact dermis integrity, and functions to anchor the layers of skin (27). This anchoring is completed by hemidesmosomes that connect epidermal cytoskeletal filaments to dermal collagenous fibrils (31). The epidermal and dermal layers are essential to the overall integrity of amphibian skin.

Though not largely studied, and thus not often described in studies examining frog integument, resident immune cells responsible for detecting and responding to pathogen exposure have been identified in frog skin (Figure 1). Intertwined amongst the skin epidermal cells of American bullfrogs, (Rana catesbeiana syn. Lithobates catesbeiana), Northern leopard frogs, (Rana pipiens syn. Lithobates pipiens), and African clawed frogs, (Xenopus laevis) are dendritic-like or Langerhans-like cells (32-34). Mast cells play an important role in inflammatory and anti-parasitic responses via degranulation of biologicallyactive compounds, such as histamine, (35) and have also been identified in histological preparations of $R$. catesbeiana skin tissues (29). Less common in the literature are sporadic reports on the presence of macrophages and lymphocytes in healthy skin tissue (7). However, during epithelial wounding or pathogen insult, recruitment of circulating immune cells to the site can occur. Although $\mathrm{T}$ cells do not appear to be resident in the skin tissues of frog species studied thus far, it is clear through skin allograft studies that cytotoxic $\mathrm{T}$ cells can infiltrate the frog skin tissue and mediate rejection of non-self-tissue and exemplifies the conservation of adaptive immunity and allograft rejection akin to mammalian studies $(32,36,37)$. In addition, B cells were also found capable of infiltrating frog skin in response to transplantation of Western clawed frog (Xenopus tropicalis) skin onto X. laevis (38).

\section{Glands}

A hallmark of amphibian skin is the presence of varied glands located in the spongious dermal layer (Figure 1) that support the vital physiological functions performed by frog skin including, but not limited to, respiration, ion regulation, water transport, immune function and predator defence $(2,6,9)$. The most ubiquitous and prominent glands in amphibian skin are mucosal glands and granular glands. Both types of glands are established in a sac-like formation surrounded by secretory cells that release granular contents and, myoepithelial cells that contract in the presence of appropriate stimuli (Figure 1) (3943). While the precise molecular mechanisms have not yet been elucidated, whole frog studies have demonstrated that electrical stimulation, injection with norepinephrine to the dorsal lymph 
sacs, or chasing a frog in a bucket for 5-10 min, stimulates the release of mucosal and granular gland contents $(17,39,40,42$, 43).

Mucosal glands secrete mucus to maintain the moisture, permeability and elasticity of the skin, all of which are necessary for amphibian homeostasis $(2,9,44)$. Though species dependent, mucosal glands are generally widely distributed across frog dorsal and ventral skin, with a higher density existing on the dorsal surface (45). The pattern of mucus discharge also varies across species. In general, terrestrial and basking frogs appear to secrete mucus at a more constant rate to aid in heat exchange and water balance. Since aquatic, arboreal and nocturnal frogs do not experience the same level of evaporative water loss, the maintenance of skin moisture is more dependent on the environment $(44,46)$. Notable exceptions to this general observation are $X$. laevis and $X$. tropicalis; although they are largely aquatic in nature, these Sub-Saharan native frogs appear to maintain continuous mucus coverage (47-49). In accordance with this, the observation of skin in Telmatobius aquatic frogs showed a more even density of granular and mucosal glands between the dorsal and ventral skin, although the mucosal glands are relatively small (50). The study of mucus production in the skin remains challenging. There is difficulty in determining natural physiological parameters of mucus production such as the volume of mucus on the skin, rate of mucus production and discharge, and the ability to determine exact concentrations of skin-secreted compounds in the mucus.

Granular glands, which include small mixed glands and other types of specialized granular glands (Figure 1), have been identified in frog skin and contain bioactive molecules involved in host defence and predator defence. Granular glands, and their contents, are arguably the best studied amphibian skin gland due to the rich diversity of biomolecules they secretenotably antimicrobial peptides and toxic alkaloids. Although commonly referred to as granular glands, these glands have the potential to secrete serous fluid, or toxic substances, and are therefore also known as serous or parotoid/venom glands $(6,41)$. Granular (serous) glands contain bioactive molecules with demonstrated broad-spectrum antimicrobial activity, many of which are classified as antimicrobial peptides (AMPs, discussed below; Figure 1) $(6,51,52)$. Granular (parotoid/venom) glands may also sequester and release toxic alkaloid biomolecules that function in predator deterrence and/or defence $(6,53,54)$. While relatively less abundant, granular glands maintain a similar distribution, and density pattern compared to mucosal glands wherein there is a higher density of granular glands on the dorsal side than the ventral side $(45,55)$. Granular glands appear to be further concentrated in specific regions of the skin, such as the central region of the skin vs. head or leg regions $(45,55)$. Similar to granular glands, small mixed glands host a reservoir of biologically active molecules or mucus and appear more evenly spread across the skin surface (29, 56). Other types of specialized glands have been identified in certain frog species with apparent functions ranging from greater granular content storage capacity, lipid secretion, and odorous secretion for predator deterrence $(40,57,58)$. Skin gland diversity, both in type and chemical composition within the glands, varies with frog species and developmental stage (59-61).

\section{SKIN AS A PHYSICAL BARRIER Cellular Junctions and Importance in Barrier Integrity}

Across all vertebrates, skin is, undoubtedly, an important physical barrier between an organism and its environment. Skin barrier integrity and permeability is maintained by cellular junctions primarily between epithelial cells and include tight junctions, gap junctions, adherens junctions, and desmosomes (4, 6264). The key proteins which comprise these junctions (and those present in mammalian skin epidermis) include claudins (claudin-1) and occludins that form tight junctions, cadherins (Ecadherin) that form adherens junctions, connexins (connexin43) that comprise gap junctions, and desmogleins (desmoglein3 ) that comprise desmosomes (62). All cellular junctions are pertinent to overall skin integrity: tight junctions connect neighbouring cells at the apical membrane, adherens junctions, and desmosomes aid in further stabilizing cell-cell adhesion, and gap junctions form channels between adjoining cells necessary for cell-cell communication (62). Tight junction proteins are detected as early as the gastrulation stage and persist until full development (4). The presence of tight junction claudin1 proteins is crucial during gastrulation in $X$. laevis embryos (65), but general observations of tight junction proteins in adult frogs are lacking. In early larvae, tripartite junctional complexes of tight junction, adherens junction, and desmosomes are observed, wherein these complexes appear to lose significant contribution from adherens junctions in larvae approaching metamorphosis and in adult frogs (4). Nonetheless, strong expression of adherens-dependent cadherin protein has been detected in adult $X$. laevis skin (66). While the presence of gap junctions and desmosomes have been reported in the skin of other vertebrates, the observation of these junctions in frogs has been limited to observations in frog embryos undergoing development, or simple presence identification in adult frogs $(67-70)$. Though all cellular junctions have been identified in frogs at different developmental stages, it is important to note that these studies have been limited to $X$. laevis and $R$. pipiens species and thus may not necessarily be representative of all frogs. Collectively, epithelial cell junctions allow for a continuous epithelial network that is relatively closed to the external environment while remaining open to the basal collagenousrich dermal layers. As such, maintenance of epithelial cellular junctions is important for barrier integrity, and thus pathogen defence, particularly considering the relatively thin epidermal layer in frogs.

Skin permeability, and thus barrier integrity, is a feat made possible by cellular junctions, wherein changes in junction proteins in response to environmental conditions regulate permeability. Tight junctions are specially known to contribute to paracellular transport of molecules (i.e., through the intercellular space and across epithelium) and thus integral to epithelial 
permeability in mammals, fish and frogs $(64,71,72)$. A plethora of studies in mammalian models describe the impact on barrier integrity, and thus barrier function, in response to various skin diseases or environmental factors $(62,71,73)$. In general, downregulation of tight junction associated proteins is widely observed among an array of human skin diseases, relating to a weakening of barrier integrity $(71,73)$. Presence of microbes, whether commensal or pathogenic, triggers an initial upregulation of genes encoding for tight junction proteins, and thus skin barrier strengthening $(71,73)$. However, persistence of pathogens leads to downregulation of gene expression for junction proteins and eventual weakening of the skin barrier (71, 73). In addition to this, studies on mammalian and fish mucosal tissue, such as the gastrointestinal tract, have defined the importance of barrier integrity in response to pathogen invasion $(12,13,15,74)$. In adult frog skin, the interplay between cellular junctions and influx/efflux of water and ions demonstrates the participation of tight junctions in acting as a selective permeable interface between the frog and its environment $(2,64,75)$. While the importance of the skin barrier and of the cellular junctions necessary for maintaining barrier integrity is well-reported in vertebrates (63, $73,76)$, the investigations on the regulation of skin barrier integrity in adult frogs in response to environmental stimuli is lacking.

Skin sloughing, a normal process in the maintenance of amphibian skin $(77,78)$, may function as an innate immune barrier. Skin sloughing may serve to remove skin-associated microbes, including pathogens (79), and the rate of skin sloughing increases with certain infections, perhaps as a mechanism to limit pathogen numbers on the skin (77). However, sloughing also exposes the underlying non-keratinized layers of the skin barrier (77). The underlying mechanism controlling the rate of skin sloughing is unclear and requires further investigation.

\section{Mucus}

Mucus plays a critical role in physical and chemical defence against pathogen invasion $(12,13,24,74)$. Recent studies observing the epidermis of $X$. tropicalis tadpoles have identified the development of multiciliated cells, ionocytes, goblet cells, and small secretory cells as integral to establishing a mucosal barrier $(49,80,81)$. Manipulation of the mucus barrier composition in $X$. tropicalis tadpoles has demonstrated the key role of the Otogelin-like structural mucin glycoprotein, that provides a $6 \mu \mathrm{m}$ thick mucosal surface barrier on tadpoles, towards conferring protection to infection of tadpoles with Aeromonas hydrophila (49). Presumably in conjunction with mucous, ciliated cells within the epidermal layer aid in removing trapped pathogens from the skin surface $(24,25,49,82)$. Current observation of the contribution of the skin mucus macromolecule composition in adult frogs to pathogen defence is lacking. In this regard, the mucus functions as a physical barrier. Yet, mucus also provides a framework for the various secretions from granular and small mixed glands, thereby contributing to the establishment of a formidable chemical barrier $(2,6,44)$.

\section{CHEMICAL BARRIERS}

\section{Antimicrobial Peptides}

In general, antimicrobial peptides (AMPs) from metazoans are gene-encoded cationic and hydrophobic molecules ranging from 12 to 50 amino acids in length (83). AMPs have been shown to aid in the direct defence against pathogens and recent investigation has uncovered the role of AMPs in modulating immune responses in human and mouse systems (84-86). Frog skin is the most abundant natural source of AMPs found on earth $(87,88)$. The diversity of AMPs in frogs may not be surprising considering the biphasic life cycles of many frog species; residing in an aquatic environment during tadpole development and transitioning to a terrestrial environment post-metamorphosis. Exposure of frogs to aquatic and terrestrial pathogens, or contact with other animals that serve as pathogen reservoirs, can enhance the incidence of disease and host mortality $(89,90)$, necessitating the evolution of a broad arsenal of antimicrobial defence. AMPs in human skin have been extensively characterized and it is generally accepted that disruption of AMP expression may lead to cutaneous disease (91-94). Similarly, a lack of AMPs on frog skin has been shown to be detrimental to adult $X$. laevis defence against the fungal pathogen $B d$ (17). It is evident that AMPs serve a significant role in the defence of frog skin against pathogens, however our understanding of the ability of frog AMPs to exert antimicrobial activity on frog pathogens is limited and knowledge surrounding their potential immunomodulatory activity in frogs is completely lacking.

\section{Structure and Diversity of Frog Skin Derived Antimicrobial Peptides}

To date, 1,078 unique AMPs have been identified from amphibians (95). Collectively, amphibian AMPs are slightly shorter than mammalian AMPs, ranging from 12 to 46 amino acids (96), with no two AMPs identical in amino acid composition. Although metazoan AMPs can be classified into one of four groups based on structure alone, including alpha-helical, beta-sheet, mixed and linear, most amphibian AMPs belong to the alpha-helical and linear groups of peptides (97, 98). The major classes of frog AMPs include: brevinins, cathelicidans, dermaseptins, esculentins, japonicins, magainins, nigrocins, palustrins, ranatuerins, ranalexins, temporins, and tigerinins (99-103), although not all AMP classes are expressed in the skin of any given frog species. For example, $X$. laevis harbours four distinct families of AMPs: caerulein precursor fragment (CPF), peptide glycine-leucine-amide (PGLa), xenopsin precursor fragments (XPF) and magainins (104). In fact, the most well-characterized frog AMPs to date are of the magainin family, magainin-1 and magainin-2 (105-107). Magainin- 1 and magainin-2 are both 23 amino acids and differ in the composition of 2 amino acids. Both magainins possess an alpha-helical structure and, like most AMPs, are amphipathic (105). The native structure and biochemistry of frog AMPs is particularly important as it dictates AMP function (108) and allows for intrinsic interactions with anionic membranes, such as those found on bacteria, fungi, viruses, and parasites (109). The association of the frog skin AMPs with anionic membranes, 
and the mechanisms by which they disrupt membrane integrity, are well-studied (110-114). The mechanisms responsible for disrupting membrane integrity are heavily influenced by lipid composition $(111,115,116)$, and include lipid flip-flop, leakage, or transmembrane integration $(111,115,117)$.

The distribution of AMPs across frog species is sporadic and some do not appear to synthesize AMPs at all (118). The ability to synthesize AMPs has been suggested to confer an evolutionary advantage to frogs but is not required for the survival of a species (118). For example, Coqui frogs (Eleutherodactylus coqui) have been shown to survive with a lack of AMPs, even when the deadly chytrid fungus, $B d$, is detected on their skin (119). However, discovery of AMPs has traditionally relied on the isolation of active fractions from amphibian skin or amphibian skin secretions and in vitro testing on microbes of human importance $(120,121)$. Thus, there may exist additional AMPs present in amphibian skin that have previously gone unidentified (122). The use of transcriptomic approaches to investigate immune function of frog skin has yielded an effective strategy to identify AMP peptide diversity across frog species, developmental stage, and environmental factors (e.g., abiotic and biotic elements) (123-125). Recent transcriptomic approaches applied to frog skin tissues have illustrated the power of untargeted approaches to identify AMPs in frog skin and suggests the existence of a greater number and diversity of AMPs produced in individual frog species $(126,127)$.

AMP secretion from granular glands is constitutive and can be inducible in response to stress, injury or infection $(99,128)$. Although difficult to quantify the rate at which peptides are secreted, concentrations of peptides in the skin mucus of $X$. laevis has been reported at $3,256 \mu \mathrm{g} / \mathrm{ml}$ (constitutive secretion) whereas the average amount of AMPs found in the skin mucosal secretions of chase-stressed or norepinephrine injected $X$. laevis (inducible secretion) was 19,581 and $41,646 \mu \mathrm{g} / \mathrm{ml}$, respectively (17). Both transcription and translation are likely responsible for the low levels of AMPs found on the skin of resting animals (17). However, few studies have examined the molecular mechanisms that lead to the inducible transcription of frog skin derived AMPs (129). In other organisms, such as humans, bovine and insects, the promoter regions of AMP genes have been found to harbour nuclear factor kappa-beta (NF- $\mathrm{kB}$ ) transcription factor binding motifs and were identified as important regulatory elements for AMP gene expression (130-132). Nuclear factor kappa-beta (NF- $\mathrm{KB})$ may also stimulate the transcription of AMP genes in frog skin as NF- $\kappa B$ has been shown to immunolocalize with the glandular cells of Chinese brown frogs (Rana dybowskii) $(129,133)$. However, nuclear localization was not apparent from these studies. In addition, NF- $\kappa \mathrm{B}$, nuclear factor NF-IL6, or cisregulatory element 2 (CRE2) transcription binding sites have been identified in the promoter regions of several AMP genes in wrinkled frogs (Rana rugosa) (134), oriental fire-bellied toads (Bombina orientalis) (135), X. laevis, and X. tropicalis (136). Future investigation is required to dissect the potential role of NF- $\kappa$ B-mediated frog skin AMP gene expression, and/or other putative transcription factors, in the maintenance of frog skin homeostasis and rapid AMP production and secretion during stress, wounding, or pathogen insult.

\section{Functions of Frog Skin Derived Antimicrobial Peptides}

\section{Direct antimicrobial activity towards frog pathogens}

Extensive investigation has demonstrated frog AMPs to exert broad-spectrum antimicrobial activity against human pathogens, including bacteria, viruses, fungi and parasites, reviewed in $(120,121,137,138)$. Only recently, however, has there been a shift in focus towards understanding whether frog skin derived AMPs are antimicrobial to frog pathogens. Emerging infectious diseases continue to decimate worldwide amphibian populations and, pathogens, such as ranaviruses and $B d$, are implicated as proximal causes in frog declines (139). It is critical to gain a further understanding of how to mitigate these diseases in order to conserve dwindling frog populations.

Frog skin derived peptides that have been tested for antipathogen activity span a diverse range of peptide families from several frog species and collectively have anti-bacterial (Tables 1, 2), anti-viral (Table 3), anti-fungal (Table 4), and anti-parasite (Table 5) activities. Frog AMPs are effective antimicrobial agents against Aeromonas sp., the causative agents of red-leg, a polymicrobial disease that is characterized by congestion of the skin, ulceration, haemorrhage, bloating, failure to respond to stimuli, and tetanic seizures (150). Differences in susceptibility to AMPs exist across Aeromonas sp. and illustrate that there exists some microbial selectivity to antimicrobial action. For example, Aeromonas caviae are highly susceptible to dermaseptin-S1 from the waxy monkey tree frog (Phyllomedusa sauvagii) with minimal inhibitory concentrations (MICs) as low as $0.5-1 \mu \mathrm{M}$, while other Aeromonas strains such as $A$. hydrophila have been reported to be resistant to dermaseptinS1 (Table 1). In addition, some bacteria appear to be completely refractory to antimicrobial peptide families. For example, AMPs (either single AMPs or mixed preparations) from $X$. laevis failed to inhibit $A$. hydrophila growth (Tables 1, 2). However, peptides from $X$. laevis were very effective against Citrobacter fruendii, another causative agent of red-leg, either alone or in combination (Tables 1, 2). In addition, magainin-2 alone was not effective against Chryseobacterium meningiosepticum but when the natural mixture of $X$. laevis skin secretions was applied to this pathogen, it was effective at reducing its growth (Tables 1,2). This evidence suggests that some peptides may require synergy to work against select pathogens.

Currently, the only viral pathogen of frogs that skin AMPs have been tested on is FV3. Frog skin AMPs have mixed antiviral efficacy on FV3. While dermaseptin-S1 from the waxy monkey tree frog, (P. sauvagii) and temporin A from the common frog (R. temporaria) were capable of inactivating FV3, magainin-2 from $X$. laevis was not able to inhibit FV3 infectivity at the AMP concentrations tested (10). The synergistic activity of AMPs towards FV3 is unknown.

Not surprisingly, the majority of frog skin derived AMPs tested against fungal pathogens of frogs have focused on $B d$ (Table 4). Based on the MICs reported, the most effective antifungal frog skin AMPs belong to X. laevis and Ranid species, the foothill yellow-legged frog (Rana boylii) and the Oregon spotted frog (Rana pretiosa) (Table 4). The promising effects of frog skin AMPs have been shown be effective against $B d$ zoospores in vitro 
TABLE 1 | Minimal inhibitory concentration (MIC) of individual frog skin-derived antimicrobial peptides against amphibian bacterial pathogens.

\begin{tabular}{|c|c|c|c|c|c|}
\hline Pathogen & Species & AMP & Sequence & MIC & References \\
\hline \multirow[t]{5}{*}{ Aeromonas caviae } & Phyllomedusa sauvagii & Dermaseptin-S1 & ALWKTMLKKLGTMALHAGKAALGAAADTISQGTQ & 0.5 & $(140)$ \\
\hline & & Dermaseptin-S2 & ALWFTMLKKLGTMALHAGKAALGAAANTISQGTQ & 1 & $(140)$ \\
\hline & & Dermaseptin-S3 & ALWKNMLKGIGKLAGKAALGAVKKLVGAES & 1 & $(140)$ \\
\hline & & Dermaseptin-S4 & ALWMTLLKKVLKAAAKAALNAVLVGANA & 0.5 & $(140)$ \\
\hline & & Dermaseptin-S5 & GLWSKIKTAGKSVAKAAAKAAVKAVTNAV & 35 & $(140)$ \\
\hline \multirow[t]{8}{*}{ Aeromonas hydrophila } & Litoria ewingii & Aurein 2.1 & GLLDIVKKWVGAFGSL & ND & $(141)$ \\
\hline & Phyllomedusa sauvagii & Dermaseptin-S1 & ALWKTMLKKLGTMALHAGKAALGAAADTISQGTQ & ND & $(142)$ \\
\hline & & Ranalexin & FLGGLIKIVPAMICAVTKKC & ND & $(142)$ \\
\hline & Rana catesbeiana & CPF & GFASFLGKALKAALKIGANLLGGTPQQ-OH & ND & $(142)$ \\
\hline & Xenopus laevis & Magainin I & GIGKFLHSAGKFGKAFVGEIMKS & ND & $(142)$ \\
\hline & & Magainin II & GIGKFLHSAKKFGKAFVGEIMNS & ND & $(142)$ \\
\hline & & Magainin II & GIGKFLHSAKKFGKAFVGEIMNS & ND & $(141)$ \\
\hline & & PGLa & GMASKAGAIAGKIAKVALKAL.NH2 & ND & $(142)$ \\
\hline \multirow[t]{5}{*}{ Citrobacter freundii } & Ascaphus truei & Ascaphin-8 & GFKDLLKGAAKALVKTVLF.NH2 & 6 & $(143)$ \\
\hline & Litoria ewingii & Aurein 2.1 & GLLDIVKKWVGAFGSL & 100 & $(141)$ \\
\hline & Leptodactylus pentadactylus & Leptoglycin & GLLGGLLGPLLGGGGGGGGGLL & 75 & $(144)$ \\
\hline & Xenopus laevis & Magainin II & GIGKFLHSAKKFGKAFVGEIMNS & $30 \mu \mathrm{g} / \mathrm{ml}$ & (99) \\
\hline & & Magainin II & GIGKFLHSAKKFGKAFVGEIMNS & 50 & $(141)$ \\
\hline \multirow{2}{*}{$\begin{array}{l}\text { Chryseobacterium } \\
\text { meningiosepticum }\end{array}$} & Litoria ewingii & Aurein 2.1 & GLLDIVKKVVGAFGSL & ND & $(141)$ \\
\hline & Xenopus laevis & Magainin II & GIGKFLHSAKKFGKAFVGEIMNS & ND & $(141)$ \\
\hline \multirow[t]{2}{*}{ Klebsiella pneumoniae } & Litoria ewingii & Aurein 2.1 & GLLDIVKKWVGAFGSL & 100 & $(141)$ \\
\hline & Xenopus laevis & Magainin II & GIGKFLHSAKKFGKAFVGEIMNS & 50 & $(141)$ \\
\hline \multirow[t]{2}{*}{ Lactococcus lactis } & Litoria ewingii & Aurein 2.1 & GLLDIVKKVVGAFGSL & 100 & $(141)$ \\
\hline & Xenopus laevis & Magainin II & GIGKFLHSAKKFGKAFVGEIMNS & 100 & $(141)$ \\
\hline \multirow[t]{2}{*}{ Pseudomonas aeruginosa } & Litoria ewingii & Aurein 2.1 & GLLDIVKKWVGAFGSL & 200 & $(141)$ \\
\hline & Xenopus laevis & Magainin II & GIGKFLHSAKKFGKAFVGEIMNS & 50 & $(141)$ \\
\hline \multirow[t]{2}{*}{ Proteus mirabilis } & Litoria ewingii & Aurein 2.1 & GLLDIVKKWVGAFGSL & ND & $(141)$ \\
\hline & Xenopus laevis & Magainin II & GIGKFLHSAKKFGKAFVGEIMNS & ND & $(141)$ \\
\hline \multirow[t]{2}{*}{ Serratia liquefaciens } & Litoria ewingii & Aurein 2.1 & GLLDIVKKWVGAFGSL & 100 & $(141)$ \\
\hline & Xenopus laevis & Magainin II & GIGKFLHSAKKFGKAFVGEIMNS & 100 & $(141)$ \\
\hline
\end{tabular}

ND indicates not determined (i.e., at the level tested, the AMP was found to have no effect on the pathogen). MIC values are reported in $\mu M$ unless indicated otherwise.

$(151,152)$ and important in $X$. laevis skin defence against $B d$ in in vivo infection studies (17). Although magainin-2 and PGLa applied individually to $B d$ and Basidiobolus ranarum, (another fungus that infects the skin of amphibians) were quite effective at reducing fungal growth, the combination highly reduced the MIC required to inhibit the fungi (i.e., was more potent) (Table 4). This is strong evidence to support that synergistic mechanisms may be more beneficial in combating particular pathogens than individual peptides. In general, the minimal inhibitory concentration of frog skin AMPs required to inhibit fungal pathogens is much higher than the amount required to inhibit bacteria or viruses (Table 4).

There is also some evidence to support the anti-parasitic role of frog skin AMPs (11). A native mixture of peptides obtained from adult $R$. catesbaeiana skin was effective at inhibiting trematode cercariae viability at all AMP mixture concentrations tested (Table 5). However, the peptide composition was not determined. To date, 12 different AMPs have been identified in $R$. catesbeiana skin secretions (95). Albeit limited in number, these studies demonstrate frog skin AMPs to be direct antimicrobial agents in innate immune defence against frog pathogens.

\section{Wound healing}

Research in murine models demonstrate that mammalian AMPs such as cathelicidan-related antimicrobial peptide are beneficial in combating skin infections in mice where they clear invading bacteria, activate immune cells and promote wound closure $(78,153-155)$. In mammalian systems, AMPs can bind cell surface receptors such as formyl peptide receptor-like-1 (FPLR1), purinergic receptors $\left(\mathrm{P}_{2} \mathrm{X}_{7}\right)$, Toll-like receptors (TLRs), chemokine receptors (CCRs), G-protein coupled receptors (GPCRs), and epidermal growth factor receptor (EGFR) to activate downstream signalling pathways to promote wound healing (156). A few studies have examined the ability of frog skin AMPs to promote wound healing in mammalian models. The application of cathelicidan-NV from the skin of a plateau frog (Nanorana ventripunctata) onto wounded mouse skin resulted in the acceleration of wound re-epithelization by direct stimulation of keratinocyte motility and proliferation (157). Cathelicidan-NV treatment also upregulated numerous genes involved in migration, proliferation and differentiation in wounded mouse skin tissue (157). Another frog skin AMP, esculentin-1a(1-21) from the common European frog (Rana 
TABLE 2 | Minimal inhibitory concentration (MIC) of skin secretions containing frog skin-derived antimicrobial peptides against amphibian bacterial pathogens.

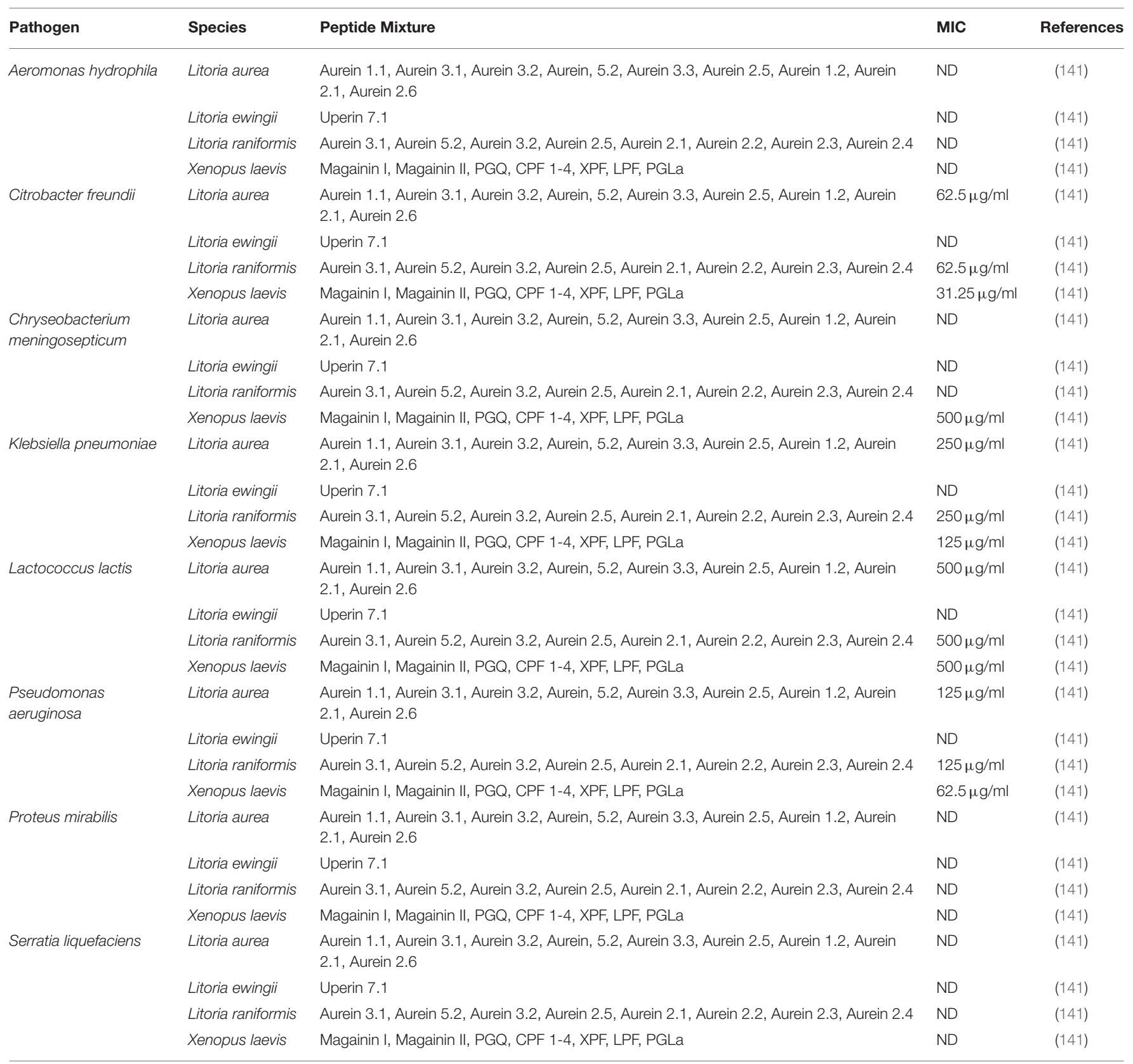

ND indicates not determined (i.e., at the level tested, the AMP was found to have no effect on the pathogen). MIC values are reported in $\mu M$ unless indicated otherwise. For peptide mixtures, the antimicrobial peptides identified through mass spectrometry are summarized.

esculenta), also promoted wound healing by stimulating human keratinocyte migration (158). Although frog skin AMPs are capable of promoting wound healing in mouse systems, and frogs are known for their remarkable wound healing ability, the function of frog skin AMPs in frog skin wound healing and the underlying cellular and molecular mechanisms are still unclear.

\section{Immunomodulation of innate immunity}

The most well-characterized human AMPs belong to the cathelicidan (LL-37) and defensin (hBD-1, hBD-2, hBD-3,
hBD-4, HD-5, and HD-6) families (156, 159, 160) and are also considered host defence peptides (HDPs) since they have been shown to modulate innate and adaptive immune responses of homologous host cells $(156,161)$. Treatment of mammalian cells with frog skin AMPs (i.e., heterologous system) revealed mammalian cells to be responsive to frog skin AMPs (157, 158, 162, 163). For example, Esculentin1a(1-21) treatment of human keratinocytes resulted in increased phosphorylation of signal transducer and activator of transcription 3 (STAT3), activating the transcription of downstream genes involved in wound healing (158). 
TABLE 3 | Inhibitory concentration $50\left(\mathrm{IC}_{50}\right)$ of frog skin-derived antimicrobial peptides against amphibian viral pathogens.

\begin{tabular}{|c|c|c|c|c|c|}
\hline Virus & Species & AMP & Sequence & $I C_{50}(\mu M)$ & References \\
\hline \multirow[t]{6}{*}{ Frog virus 3} & Phyllomedusa sauvagii & Dermaseptin-S1 & ALWKTMLKKLGTMALHAGKAALGAAADTISQGTQ & 12 & $(10)$ \\
\hline & Rana catesbeiana & Skin peptide mixture & & ND & $(10)$ \\
\hline & Rana pipiens & Skin peptide mixture & & ND & $(10)$ \\
\hline & Rana temporaria & Temporin A & FLPLIGRVLSGIL.NH2 & 58 & $(10)$ \\
\hline & Xenopus laevis & Magainin II & GIGKFLHSAKKFGKAFVGEIMNS & ND & $(10)$ \\
\hline & & PGLa & GMASKAGAIAGKIAKVALKAL.NH2 & ND & $(10)$ \\
\hline
\end{tabular}

ND indicates not determined (i.e., at the level tested, the AMP or skin peptide mixture was found to have no effect on the pathogen). Values are reported in $\mu M$ where available.

Cathelicidan-NV induced fibroblast-to-myofibroblast transition and also significantly increased collagen production in the wound (157). Another frog skin AMP, brevinins-1Pa, from R. pipiens, stimulated the release of insulin from rat pancreatic islet cells (162). Insulin is known to play a role in keratinocyte function by inducing migration through the PI3-Akt-RhoA network (164). Several AMPs from X. laevis (CPF, magainin-1, magainin2, PGLa) and the Taiwanese frog (Holobatrachus rugulosas) tigerinin-1R have been shown to stimulate the secretion of glucagon-like peptide 1 (GLP-1) from GLUTag cells (163). GLP-1 is an immunomodulatory molecule and decreases the inflammatory response during allergen and infection-induced inflammation (165). The experimental evidence suggests that various frog skin AMPs have a substantial effect on mammalian cells processes such as cell migration, inflammation, immunity and repair $(158,164,166)$. Unfortunately, the functions of frog skin AMPs on frog cells (i.e., homologous system) have not been explored and whether frog skin AMPs act as HDPs in frogs remains unknown.

\section{Alkaloids}

Lipid-soluble alkaloid compounds are believed to originate from the amphibian diet, largely from insects (167). Identification of these alkaloid compounds has mainly focused on those excreted by frogs in the Dendrobatidae family (poison dart frogs) with observation from over 150 species $(168,169)$. Nonetheless, toxic alkaloid substances have also been observed in Eleutherodactylidae, Leptodactylidae, Mantella, Myobatrachidae, and Ranidae frogs (54, 169171). Toxic alkaloids are primarily involved in predation avoidance, however, a few also participate in defence against microbes $(167,172)$. Readers interested in alkaloid compound diversity are referred to reviews on this topic $(169,173)$.

\section{EPITHELIAL CELLS AS MICROBIAL SENSORS AND INITIATORS OF INNATE IMMUNE RESPONSES}

Epithelial cells are emerging as crucial contributors to innate immune responses through the detection of microorganismsboth commensal and pathogenic-in the external environment $(174,175)$ through the use of pattern recognition molecules. A relatively limited number of germ-line encoded pattern recognition receptors (PRRs) detect non-self and damage signals and these recognition events are crucial to initiating innate immune response. Classes of PRRs are generally divided into transmembrane and cytosolic PRRs. Transmembrane receptors include TLRs, C-type-lectin like receptors (CLRs), and scavenger receptors, while cytosolic PRRs include retinoic acid inducible gene- (RIG-) I-like receptors (RLRs), nucleotidebinding oligomerization domain- (NOD-) like receptors (NLRs), and various cytosolic DNA sensors (176). Collectively, PRRs recognize a variety of pathogen-associated molecular patterns (PAMPs), also known as microbial-associated molecular patterns (MAMPs), including lipopolysaccharide, peptidoglycan, lipopeptides, flagellin, single stranded RNA, double stranded RNA, double stranded DNA, carbohydrate structures, as well as other PAMPs (176). PRRs also recognize damageassociated molecular patterns (DAMPs) released upon cellular stress (177). Ligand sensing by PPRs leads to intracellular signalling cascades that regulate the transcription of genes encoding for pro-inflammatory, chemoattractive and antiviral functions (176). In accordance with the location of epithelial cells at the host-environment interface, epithelial cells in mammalian models have been shown to express diverse PRRs including TLRs (178), RLRs (179), and NLRs (180) to sense invading microorganisms and initiate innate immune responses.

Few studies have focused on the characterization of amphibian PRRs (e.g., ligands, signalling pathways, downstream gene targets), let alone their role in amphibian skin epithelial cell biology. Yet, it is evident that cells within frog skin tissue are capable of sensing bacterial, viral and fungal pathogens, including commercially available mimics of PAMPs, and initiate innate immune responses through the upregulation genes encoding for pro-inflammatory cytokines, anti-viral cytokines, antimicrobial peptides, and other immune proteins (181-183). The cell type(s) and receptors involved in microbial recognition by amphibian skin tissues are largely unknown. Thus, much of our basis for understanding the role of frog skin epithelial cells to microbial detection is limited to the identification of key pattern recognition molecules in the frog genome and implied conservation of their function based on limited expression data in frog skin tissues. In the below subsections, we summarize the current state of knowledge surrounding the presence of genes encoding for pattern recognition molecules identified in frog genomes and the expressions of these genes in frog skin tissues. 
TABLE 4 | Minimal inhibitory concentration (MIC) of frog skin-derived antimicrobial peptides against amphibian fungal pathogens.

\begin{tabular}{|c|c|c|c|c|c|}
\hline Pathogen & Species & AMP & Sequence & MIC $(\mu \mathrm{M})$ & References \\
\hline \multirow{22}{*}{$\begin{array}{l}\text { Batrachochytrium } \\
\text { dendrobatidis }\end{array}$} & Hylomantis lemur & Phylloseptin-L1 & LLGMIPLAISAISALSKL & 100 & (145) \\
\hline & Rana boylii & Brevinin-1BYa & FLPILASLAAKFGPKLFCLVTKKC & 12.5 & $(146)$ \\
\hline & & Brevinin-1BYC & FLPILASLAAKLGPKLFCLVTKKC & 6 & (146) \\
\hline & Rana boylii & Metamorph AMP mixture & & $12.5-50 \mu \mathrm{g} / \mathrm{ml}$ & $(146)$ \\
\hline & Rana catesbeiana & Ranalexin & FLGGLIKIVPAMICAVTKKKC & 9 & (142) \\
\hline & Rana muscosa & Ranatuerin-2Ma & GLLSSFKGVAKGVAKNLAGKLLEKLKCKITGC & 50 & $(147)$ \\
\hline & & Ranatuerin-2Mb & GIMDSVKGVAKNLAAKLLEKLKCKITGC & 25 & $(147)$ \\
\hline & & Temporin-1M & FLPIVGKLLSGLL.NH2 & 100 & $(147)$ \\
\hline & & Brevinin-1PRd & FLPMLAGLAASMVPKLVCLITKKC & 12.5 & (148) \\
\hline & & Esculentin-2PRa & GVFSFLKTGAKLLGSTLLKMAGKAGAEHLACKATNQC & 25 & (148) \\
\hline & & Esulentin-2PRb & GIFSALAAGVKLLGNTLFKMAGKAGAEHLACKATNQC & 12.5 & $(148)$ \\
\hline & & Ranatuerin-2PRa & GILDSFKGVAKGVAKDLAGKLLDKLKCKITGC & 25 & (148) \\
\hline & & Rantuerin-2PRb & GILDTFKGVAKGVAKDLAVHMLENLKCKMTGC & 50 & $(148)$ \\
\hline & & Rantuerin-2PRc & GILDSFKDVAKGVATHLLNMAKCKMTGC & 100 & (148) \\
\hline & & Rantuerin-2PRe & GIMNTVKDVATGVATHLLNMVKCKITGC & 100 & (148) \\
\hline & & Rantuerin-2PRf & GILDTFKGVAKGVAKDLAVHMLEKLKCKMTGC & 25 & (148) \\
\hline & & Rantuerin-2PRg & GILSSFKDVAKGVAKNVAAQLLDKLKCKKITGC & 50 & (148) \\
\hline & & Rantuerin-2PRh & GILDTVKGVAKDVAAHLLNMVKCKITGC & 50 & $(148)$ \\
\hline & & Magainin II & GIGKFLHSAKKFGKAFVGEIMNS & 100 & $(142)$ \\
\hline & & PGLa & GMASKAGAIAGKIAKVALKAL.NH2 & 50 & (149) \\
\hline & & PGLa & GMASKAGAIAGKIAKVALKAL.NH2 & 3.1 & $(142)$ \\
\hline & & Magainin II + PGLa (1:1 ratio) & & 12.5 & $(142)$ \\
\hline \multirow{3}{*}{$\begin{array}{l}\text { Basidiobolus } \\
\text { ranarum }\end{array}$} & Xenopus laevis & Magainin II & GIGKFLHSAKKFGKAFVGEIMNS & 12.5 & $(142)$ \\
\hline & & PGLa & GMASKAGAIAGKIAKVALKAL.NH2 & 3.1 & $(142)$ \\
\hline & & Magainin II + PGLa (1:1 ratio) & & 0.8 & (142) \\
\hline
\end{tabular}

MIC values are reported in $\mu M$ unless indicated otherwise. For peptide mixtures, the antimicrobial peptides identified through mass spectrometry are summarized.

\section{Toll-Like Receptors (TLRs)}

The first glimpse into the frog TLR multigene family came about through a bioinformatics approach to study the evolution of vertebrate TLRs and was spearheaded as a result of the influx of draft genome sequences of fish (e.g., Takifugu rubripes) and frog (X. tropicalis) (184). Molecular evolutionary analysis demonstrated that TLRs are evolving at approximately the same, slow rate and are under strong purifying selection, presumably to ensure maintenance of TLR function both in terms of ligand recognition and initiation of intracellular signalling cascades (184, 185). Through the construction of molecular trees, six major TLR families emerged (Table 6), each encompassing subfamilies of TLRs that that recognized a general set of PAMPs/MAMPs $(184,186)$. At least 19 TLR genes were identified in the $X$. tropicalis genome (JGI 4.1) and included orthologues of both mammalian and fish specific (e.g., TLR21, TLR22) TLRs. Characteristic of the mammalian TLR2 family is the ability of TLR2 family members to form heterodimeric pairs with TLR2 
TABLE 5 | Minimal inhibitory concentration (MIC) of frog skin-derived antimicrobial peptides against amphibian parasites.

\begin{tabular}{|c|c|c|c|c|}
\hline Parasite & Frog species & $\begin{array}{l}\text { Antimicrobial } \\
\text { peptide }\end{array}$ & $\begin{array}{c}\text { MIC } \\
(\mu \mathrm{g} / \mathrm{ml})\end{array}$ & References \\
\hline Manodistomum & Rana catesbeiana & $\begin{array}{l}\text { Adult AMP } \\
\text { mixture }\end{array}$ & 65 & (11) \\
\hline Echinostoma & Rana catesbeiana & $\begin{array}{l}\text { Adult AMP } \\
\text { mixture }\end{array}$ & 58 & (11) \\
\hline Ribeiroia & Rana catesbeiana & $\begin{array}{l}\text { Adult AMP } \\
\text { mixture }\end{array}$ & 35 & (11) \\
\hline Armatae & Rana catesbeiana & $\begin{array}{l}\text { Adult AMP } \\
\text { mixture }\end{array}$ & 20 & $(11)$ \\
\hline Alaria & Rana catesbeiana & $\begin{array}{l}\text { Adult AMP } \\
\text { mixture }\end{array}$ & 19 & (11) \\
\hline
\end{tabular}

(176) to recognize a diverse set of ligands, and is presumed to also occur in frogs (184). In X. tropicalis the TLR2 family encompasses one TLR1, two TLR2, two TLR6, and four TLR14 subfamily members and appears to lack the TLR10 subfamily (Table 6) $(184,186)$. The TLR14 subfamily appears to have expanded in $X$. tropicalis, and possibly in other frogs, to four TLR14 subfamily members that are hypothesized to form heterodimeric pairs with TLR2, similar to other subfamily members of the TLR2 family (184). One member of each of the TLR3 (senses dsRNA), TLR4 (senses LPS) and TLR5 (senses flagellin) families were identified in $X$. tropicalis (Table 6) $(184,186)$. However, the putative $X$. tropicalis tlr4 gene does not appear to encode for a transmembrane region based on in silico structural prediction (186). Genes for $c d 14$ or $m d-2$, involved in TLR4 function in mammals (176), have not been identified in the $X$. tropicalis genome and thus the function of the putative $X$. tropicalis TLR4 as an LPS sensor is uncertain (186). Another interesting deviation from the mammalian system is the predicted presence of a soluble TLR5, termed tlr5s (184), similar to the soluble TLRs found in fish species (188). The tlr5s gene is predicted to encode for the extracellular leucine rich repeat (LRR) region and is lacking the transmembrane and intracellular TIR signalling domains suggesting it may act as a soluble receptor to potentially regulate TLR5 signalling (184). The TLR7 family is crucial for sensing endosomal PAMPs in mammals (189) and a single orthologue of $\operatorname{tr} 7$ and $\operatorname{tr} 9$, and two orthologues of $\operatorname{tr} 8$ were identified in $X$. tropicalis (Table 6) $(184,186)$. Lastly, a single orthologue of TLR12, TLR13, TLR21 and TLR22 subfamilies were identified in $X$. tropicalis (Table 6) (184, 186). In silico prediction of $X$. tropicalis TLRs protein structures revealed overall similar $X$. tropicalis TLR structure to corresponding human TLR orthologues, including a similar size and number of LRR domains, transmembrane region and an intracellular TIR domain (186).

Aside from the identification of TLR genes in few frog species $(125,183,184,186)$, little investigation has focused on characterization of frog TLRs, and their role in frog skin innate immunity. In $X$. laevis, the TLR genes, including the putative $t l r 4$, are expressed in the skin of tadpoles and adults $(181,186)$. Transcriptomic studies from skin of healthy Japanese brown frogs (Rana japonica), Montane brown frog (Rana
TABLE 6 | Toll-like receptor genes identified in frog species.

\begin{tabular}{|c|c|c|c|c|}
\hline Family & Subfamily & X. tropicalis & X. laevis & Other frogs \\
\hline \multirow[t]{5}{*}{ TLR2 } & TLR1 & $\operatorname{tr} 1(186)$ & $\operatorname{tr} 1^{\$}(186)$ & B. maxima $\$$ (183) \\
\hline & TLR2 & t/r2.1, t/r2.2 (186) & $\operatorname{tr} 2^{\$}(186)$ & $\begin{array}{l}\text { R. japonica } \$(187) \\
\text { R. ornativentris } \$ \\
(187) \\
\text { R. tagoi tagoi }{ }^{\$}(187) \\
\text { B. maxima } \$(183)\end{array}$ \\
\hline & TLR6 & 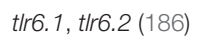 & $\operatorname{tr} 6^{\$}(186)$ & B. maxima $\$(183)$ \\
\hline & TLR10 & $\begin{array}{l}\text { Not identified } \\
(184,186)\end{array}$ & & \\
\hline & $\begin{array}{l}\text { TLR14 and } \\
\text { TLR14-like }\end{array}$ & $\begin{array}{l}\text { tIr14.1, t/r14.2, } \\
\operatorname{tir} 14.3, \operatorname{tir} 14.4 \\
(184,186)\end{array}$ & $\operatorname{tr} 14^{\$}(186)$ & \\
\hline TLR3 & TLR3 & t/r3 $(184,186)$ & $\operatorname{tr} 3^{\$}(186)$ & B. maxima $\$$ (183) \\
\hline TLR4 & TLR4 & $\begin{array}{l}\text { tIr4 (184) } \\
\text { tIr4 found in } \\
\text { non-coding region } \\
(186)\end{array}$ & $\operatorname{tr} 4^{\$}(186)$ & $\begin{array}{l}\text { R. japonica } \$(187) \\
\text { R. ornativentris } \$ \\
(187) \\
\text { R. tagoi tagoi }{ }^{\$}(187) \\
\text { B. maxima }{ }^{\$}(183)\end{array}$ \\
\hline TLR5 & TLR5 & $\begin{array}{l}\text { tIr5 }(184,186) \\
\text { tIrs5 }^{*}(184)\end{array}$ & $\begin{array}{l}\operatorname{t} r 5^{\$} \\
(184,186)\end{array}$ & B. maxima $\$(183)$ \\
\hline \multirow[t]{3}{*}{ TLR7 } & TLR7 & $\operatorname{tIr} 7(184,186)$ & $\operatorname{tr} 7^{\$}(186)$ & B. maxima ${ }^{\$}(183)$ \\
\hline & TLR8 & t/r8.1, t/r8.2 (186) & $\operatorname{tr} 8^{\$}(186)$ & B. maxima $\$$ (183) \\
\hline & TLR9 & tIr9 $(184,186)$ & $\operatorname{tr} 9^{\$}(186)$ & \\
\hline \multirow[t]{4}{*}{ TLR12 } & TLR12 & $\operatorname{tr} 12(186)$ & $\operatorname{tr} 12^{\$}(186)$ & \\
\hline & TLR13 & t/r13 $(184,186)$ & $\operatorname{tr} 13^{\$}(186)$ & \\
\hline & TLR21 & tIr21 (184, 186) & $\operatorname{tr} 21^{\$}(186)$ & \\
\hline & TLR22 & t/r22 $(184,186)$ & t/r22\$ (186) & \\
\hline
\end{tabular}

$X$. tropicalis tir genes shown in bold are predicted to contain introns, non-bolded genes are predicted to be intronless. "Soluble short form lacks the transmembrane and TIR domains. \$Sequences were detected by RT-PCR with CDNA as a template, gene sequence structure not reported.

ornativentris), Tago frog (Rana tagoi) (187), and the Yunnan firebelly toad (Bombina maxima) (183) have demonstrated the presence of $t l r$ transcripts in skin tissue and further support the important role of anuran skin and the cells within as important sensors of microbes and regulators of innate immunity. Indeed, several transcriptomic studies of anuran skin tissues, including Ranidae, Megophryidae, Rhacophoridae, and Bufonidae families, revealed the enrichment of transcripts involved in processes reflected in the gene ontology terms "immune system process," "immune system," and "signal transduction," further supporting anuran skin as an immune organ (123-125). However, only a single study has examined the potential sensing of a PAMP by a frog TLR; LPS $(10 \mu \mathrm{g} / \mathrm{ml})$ treatment of $R$. temporaria frog urinary bladder epithelial cells positive for TLR4 (albeit demonstrated through the use of non-homologous anti-TLR4 antibody) triggered epithelial cell activation through an NF- $\mathrm{B}$ dependent mechanism (190). Although these urinary bladder epithelial cells appear to be LPS responsive, unequivocal evidence that TLR4 is responsible for LPS sensing is lacking.

\section{Cytosolic Pattern Recognition Sensors}

RLRs, NLRs, and cytoplasmic DNA sensors are vital cytosolic pattern recognition molecules involved in initiating pro-inflammatory and anti-viral responses (191). RLR family 
members include retinoic acid-inducible gene-I (RIG-I), melanoma differentiation-associated gene 5 (MDA5), and laboratory of genetics and physiology 2 (LGP2) (191). In mammals, RIG-I and MDA5 bind viral RNA via the common RNA helicase domain and ligand recognition results in activation of interferon regulatory factor 3 and NF-kB transcription factors to initiate transcription of an anti-viral interferon response (191). LGP2 is known to interfere with viral RNA binding to RIG-I and MDA5 (192). While rig-i, mda5, and lgp2 genes have been identified in the $X$. tropicalis genome (193) and rig- $i$ and $m d a 5$ found expressed in frog skin $(181,183)$, little else is known about the role of RLRs in anurans.

In mammals, NLRs are organized into five subfamilies (NLRA, NLRB, NLRC, NLRX, NLRP) based on the N-terminal effector domain and collectively sense a wide range of MAMPs (194). NLR activation leads to receptor oligomerization and formation of the inflammasome and activation of downstream inflammatory caspases that cleave interleukin 1 cytokine family members (IL-1, IL-18) (194). Seven NLR genes were identified in the $X$. tropicalis genome, including NLRA/CIITA, NLRC1/NOD1, NLRC3, NLRC4, NLRC5, and NLRX1, while NLRC2/NOD2 appears to be absent $(195,196)$. Members of all five NLR subfamily were identified in the B. maxima skin transcriptome including NLRA/CIITA, NLRB/NAIP, NLRC1/NOD1, NLRC3, NLRC5, NLRP1, NLRP3, NLRP5, and NLRX1 (183).

In addition to RLRs and NLRs, cytosolic DNA sensors are also expressed in frog skin. Amphibian skin transcriptomes from the Chinese giant salamander (Andrias davidianus), Asiatic toad (Bufo gargarizans), and black-spotted frog (Rana nigromaculata) revealed the presence of transcripts in the "cytosolic DNAsensing pathway" and the expression of a DNA-dependent RNA polymerase III that functions as a cytosolic DNA sensor by transcribing an RNA copy for recognition by RIG-I (124), suggesting a conserved evolutionary anti-microbial mechanism. However, an AIM-2-like receptor, another cytosolic DNA sensor that can lead to inflammasome activation, is seemingly absent in X. tropicalis (195).

\section{IMPACT OF ENVIRONMENT ON HOST BARRIERS}

\section{Abiotic Factors}

Frogs are to the environment as canaries were to coal mines. They are an important indicator species and their physiology is heavily influenced by the environment (197199). Most studies examining the impact of abiotic factors on amphibian skin have focused on AMPs. Temperature, dehydration, shade, acidification, oxygen and altitude $(200,201)$ have been documented to influence frog skin AMPs. For example, increased environmental temperatures (from 5 to $30^{\circ} \mathrm{C}$ ) triggered brevinin-1SY AMP production in $R$. sylvatica skin tissue (200). Albeit, the underlying mechanism for the production of brevinin-1SY at higher temperatures is unclear, increased microbial colonization of the skin at the higher temperature or increased transcriptional/translational kinetics may be involved.
Microbes on the skin surface may stimulate PRRs on the membrane of epidermal cells, leading to downstream signalling that potentially induces transcription of AMP genes with NF$\kappa \mathrm{B}$ in the promoter region (202). Cold stress in mammals (203) and cultured amphibian primary epidermal cells (204) has been shown to reduce the rates of transcription and translation, leading to decreased global protein synthesis. Thus, low body temperatures of $R$. sylvatica may have led to a near halt in AMP synthesis. In $R$. catesbeiana tadpoles, shade and acidification of the environment have been shown to modulate the production and bioactivity of AMPs (201, 205). Another environmental factor that has an effect on AMPs is hydration status. Dehydration in $R$. sylvatica increased the expression of brevinin-1SY in the skin (201). In addition to dehydration, other environmental stressors such as anoxia or freezing, also enhances the antimicrobial activity of $R$. sylvatica brevinin-1SY against select microbial strains (201). Decreased oxygen availability or hypoxia, has been associated with an increased number of granular glands in Tibetan frog (Nanorana parkeri) middorsal skin (199). The biological significance of increased granular glands found in hypoxic conditions is unknown. It is evident from these findings that the regulation of AMPs and the diversity among the AMP secretome is complex but is shaped by the environment.

\section{Chemical Contaminants}

Anthropogenic factors, such as pesticides, also impair immunity and can reduce chemical skin defences $(146,206)$. Compared to mammalian skin, frog skin has significantly greater uptake potential of xenobiotics that can bioconcentrate and may be detrimental to frog health (207-209). In some instances, the chemicals exert a direct effect on the skin epidermal cells. For example, short-term exposure of Italian pool frog (Pelophylax bergeri) skin cultures to cadmium resulted in alteration and disorganization of the skin epidermal layers, and ultimately induced cellular and molecular stress responses (210). In addition, exposure to environmental contaminants has been documented to directly affect the paracellular transport of ions across frog skin $(211,212)$, wherein cellular junctions play an important role in ion transport $(2,64,75)$. Chemical contaminants can also impact host immune function resulting in altered host resistance to pathogens. Pesticide exposure has been shown to influence antiviral immunity in larval and adult frogs that led to increased susceptibility to pathogen invasion (213-215). It is then proposed that the potential for chemical contaminants to impact epidermal organization and alter frog skin permeability leads to increased pathogen susceptibility and host mortality. In general, while these studies are comprehensive at analysing either the impact of contaminants on amphibian skin or effect on ion permeability and pathogen susceptibility, none appear to directly report the regulation of cellular junctions in combination with pathogen susceptibility. Besides the effects of pesticides on skin permeability and pathogen susceptibility, specific pesticides such as carbaryl, have also been shown to significantly reduce frog skin peptide levels, but not bioactivity $(146,216)$. 


\section{UV Radiation}

Overexposure of frogs to UV-B radiation, in part due to deforestation and habitat loss, results in damage to the epidermal layer of larval and adult frogs (217, 218). Skin damage is characterized by epidermal shedding and sore formation, causing pronounced detrimental effects to maintenance of skin integrity and to physiological processes such as water and ion transportation $(217,218)$. Though largely unexplored in frogs, it is suggested that UV radiation breaches the skin barrier and induces host immunosuppression, causing the frog to be more susceptible to both pathogen invasion and exposure to chemical contaminants, leading to host mortality (218). Simultaneous exposure of larval $X$. laevis to pesticides and UV-B radiation resulted in higher mortality and instances of malformations, including those of the skin $(208,219)$. The interplay between UV and chemical exposure on frog skin immunocompetence, however, is not well-studied. While extensive research has been conducted in mammalian and fish models to elucidate the impact of irradiation on skin barrier integrity $(220,221)$, this is largely lacking in amphibian models.

\section{Pathogens}

Much of our understanding of frog skin-pathogen interactions with FV3 and $B d$ derives from studies using $X$. laevis as a model (17). FV3 is transmitted through the environment, either through direct contact, indirect contact or consumption of infected carcasses $(222,223)$ and therefore must cross either the skin epithelial barrier or the gut epithelial barrier. Adult $X$. laevis are relatively resistant to FV3 and generally recover from mild symptoms 3-4 weeks after infection (18, 224, 225), whereas tadpoles are highly susceptible to FV3 infection (226). While the majority of X. laevis-FV3 research has bypassed the skin barrier via intraperitoneal injection of virus into the host $(18,227-229)$, water-bath exposure of healthy tadpole and adult $X$. laevis to FV3-infected frogs in the same tank revealed that healthy individuals become infected with FV3 within $3 \mathrm{~h}$ of exposure (230). A key symptom of FV3 infection in susceptible developmental stages or frog species is the formation of skin lesions, skin shedding, and epidermal cell necrosis $(231,232)$. It is proposed that loss of the skin barrier during FV3 infection allows for increased pathogen entry and ultimately leads to mortality in susceptible hosts, stressing the overall importance of the skin barrier and barrier integrity. While the precise contribution of frog skin innate immunity to FV3 resistance is unclear, initial studies suggest the initiation of a type I interferon response in the skin tissue of adults, compared to a type III interferon response in the skin of susceptible tadpoles, is important in conferring protection against FV3 viral entry and replication, and host mortality outcomes $(181,233)$.

Infection of susceptible frogs with $B d$ results in the disruption and cellular death of epidermal layers, resulting in host mortality $(77,234,235)$. Comprehensive transcriptomic analyses on the skin of frogs infected with $B d$ revealed significant transcriptional regulation in the skin with generalized decreases in collagen, fibrinogen, elastin and keratin pathway transcript abundance, which corroborates with the observed disruption in epidermal skin integrity and loss of osmotic balance (236). Furthermore, a generalized lack of gene upregulation for key pro-inflammatory genes was observed, and instead an increase in transcripts for anti-inflammatory markers such as NF- $\mathrm{B}$ inhibitors were seen (236) suggesting $B d$ may possess immunosuppressive capacity to limit frog skin innate immune defences and activation of underlying immune cells. Overall, these studies somewhat parallel observations in skin from FV3-infected frogs and suggests the loss of skin structural integrity may allow for increased pathogen entry and host mortality.

With the new era of transcriptomics approaches, untargeted transcriptomic molecular approaches have unveiled new insights into the impressive array of physiological functions performed by amphibian mucosal skin epithelium. Recent studies have analysed and compared the transcriptome of 3 anuran families to unveil genes involved in biosynthesis, metabolism, immunity, defence processes, and identification of antimicrobial peptides (123). In addition, transcriptomic studies have been performed on Ranidae and Centrolenidae frogs, species that are largely susceptible to pathogens plaguing amphibian populations, and included skin-specific immune gene expression analysis $(125,237,238)$. However, the underlying molecular basis and mechanisms governing resistance and susceptibility of frog species are not well-understood. Further comparisons of frog skin transcriptomes from resistant and susceptible frogs will aid in elucidating the contribution of amphibian skin to resistance against lethal amphibian pathogens.

\section{MICROBIOME}

In mammals, the skin microbiome plays a significant role in the defence against pathogens, injury and infection (239). Recently, attention has turned to elucidating the contribution of the frog skin microbiome in innate immune defences to emerging infectious diseases of amphibians, and in particular to $B d$. The frog skin microbiome is seeded by microbes in the external environment (240-242) and shaped by the selective skin microenvironment $(241,243,244)$. External contributors to the frog microbiome are the aquatic and soil environments (107) that are believed to serve as a reservoir for the frog skin microbiota (245-248), though horizontal transmission (e.g., during mating) (249), or vertical transmission (i.e., parent to offspring, although not common) (244) are also potential sources. In general, the main bacterial phyla found on frog skin consists mainly of Proteobacteria and Actinobacteria, however, this may vary across frog species, habitat and environmental factors (250-252). Not surprisingly, the frog skin microbiome is influenced by life stage $(253)$, body region $(254,255)$, diet (254), capture site (256), habitat, captivity $(254,257)$, exposure to anthropogenic contaminants $(258,259)$, and treatment with antibiotics (260). While some of these factors may directly influence commensal skin microbes, it is possible that these same factors influence AMP gene expression, secretion of AMPs onto the skin, and AMP bioactivity. Initial studies have shown that the presence of commensal frog skin microbes is important for AMP synthesis (129). Thus, in light of the documented antimicrobial activity of many frog AMPs (Tables 1-4), the altered levels and 
activities of frog AMPs on the skin may also contribute to alteration of frog skin microbial communities. Depending on the conditions, skin microbiome dysbiosis may contribute to disease susceptibility in frogs, as observed in other vertebrates (252).

As in other vertebrates (239), symbiotic bacteria on frog skin appear to play an important role in defence against invading pathogens. Investigations of frog skin commensal microbes have revealed certain commensal bacteria to produce metabolites with anti- $B d$ activity $(128,241,242,261,262)$. The frog skin commensal bacteria that produce anti-fungal metabolites are documented in the Antifungal Isolates Database (120, 263). Interestingly, metabolites produced by bacteria present on frog skin can also synergize with AMPs on the skin to inhibit $B d$ (264). Despite the exciting advances in the contribution of frog skin microbial communities to innate immune functions of frog skin, much remains to be elucidated in terms of host-microbiomeenvironment interplay.

\section{CONCLUDING REMARKS AND FUTURE PERSPECTIVES}

Research on the innate immune functions of amphibian skin is emerging and beginning to shift from silos (e.g., investigating skin structure, AMPs or microbiomes) to integrative studies in which multiple facets of skin innate immunity are considered. This approach is critical to elucidating the complex hostpathogen-environment interactions at the skin interface that are participating in amphibian susceptibility to emerging infectious diseases and underpin the global decline in amphibian populations. However, it is evident from the literature that large knowledge gaps exist within each of the skin innate immune barrier silos and in understanding the intricate web of cellular and molecular mechanisms that function to maintain skin homeostasis and rapidly fend against pathogen insult and/or mediate wound healing. We believe there exists an imminent need to unravel the contribution of physical, chemical, cellular and microbiological barriers, to the innate immune function of amphibian skin and the abiotic and biotic environmental factors that regulate skin immunocompetency. Research on the presence and regulation of skin epithelial cell junction proteins under normal and stress conditions would provide vital information on which junction proteins are involved in skin epithelial cell junctions and under what conditions these junction proteins may be controlled to regulate skin permeability. The involvement of the diversity of junction proteins in amphibian skin barrier function is unknown. Little is known of the epithelial cells themselves in terms of the expressions of pattern recognition receptors, the localization of surface receptors (e.g., presence on apical or basal membrane), the role of epithelial cells in the direct sensing of non-self (and distinguishing commensal vs. pathogenic microbes) and in the initiation of innate immune responses leading to the direction of adaptive immune responses. Scrutiny of the literature yielded little information on amphibian PRRs themselves, save for their presence in the frog genome and apparent overall conservation of the signalling pathways as determined by molecular evolutionary analyses. The functional identification of PRR ligands, signalling pathways and downstream gene targets remains untouched. While the identification of amphibian AMPs and the characterization of their antimicrobial activity to human pathogens has been a topic of extensive investigation, comparatively little has been done to examine the antimicrobial activity of frog AMPs on frog pathogens. Virtually nothing is known of their contribution to amphibian skin wound healing or putative innate immune modulation functions, and if present, the receptors through which they bind, the signalling pathways they activate or the gene targets they regulate the expression of. An increasing number of researchers are surveying the commensal microbes present on frog skin, how frog skin microbial communities change with species, life stage, environment and presence of pathogens, yielding insight into the role of these microbes in defending against pathogenic insult. Yet much remains to be uncovered regarding how the frog host creates a permissive niche for certain microbial species while restricting others. Microbemicrobe interactions may also contribute to establishment of "healthy microbiomes" and deeper investigation into the metabolic capacities of commensal microbes will likely yield insight into the maintenance of certain microbial communities. Perhaps further characterization of the skin microbiome may foster the development of deployable "environmental probiotics" to habitats in which threatened or endangered amphibians reside as a way to seed the amphibian skin microbiome, thereby aiding in commensal microbe-mediated defence against frog pathogens. Achieving a complete understanding of skin innate immune function and the factors that affect skin barrier homeostasis may inform environmental policies aimed at conservation of amphibians to mitigate detrimental stressors that alter skin integrity and innate immune competency, or to develop strategies to safeguard threatened amphibians from further disease and population declines.

\section{AUTHOR CONTRIBUTIONS}

All authors listed have made a substantial, direct and intellectual contribution to the work, and approved it for publication.

\section{FUNDING}

Natural Sciences and Engineering Research Council (NSERC) Discovery Grant (RGPIN-2017-04218) awarded to BK. JV and MB-M received financial support in the form of Graduate Teaching Assistantships, Science Graduate Experience Awards, and Science Graduate Student Awards from the Department of Biology and University of Waterloo.

\section{ACKNOWLEDGMENTS}

The authors would like to thank Marie-Claire Wasson for their assistance in finding references for the manuscript and the two reviewers for their thoughtful comments that aided in the improvement of the manuscript. 


\section{REFERENCES}

1. AmphibiaWeb. Available online at: www.amphibiaweb.org (2018). (Accesssed October 29, 2018).

2. Lillywhite HB. Water relations of tetrapod integument. J Exp Biol. (2006) 209:202-26. doi: 10.1242/jeb.02007

3. Suzuki M, Hasegawa T, Ogushi Y, Tanaka S. Amphibian aquaporins and adaptation to terrestrial environments: a review. Comp Biochem Physiol Part A Mol Integ Physiol. (2007) 148:72-81. doi: 10.1016/j.cbpa.2006.12.021

4. Farquhar MG, Palade GE. Cell junctions in amphibian skin. J Cell Biol. (1965) 26:263-91. doi: $10.1083 /$ jcb.26.1.263

5. Elkan E. Mucopolysaccharides in the anuran defence against desiccation. $J$ Zool. (1968) 155:19-53. doi: 10.1111/j.1469-7998.1968.tb03028.x

6. Toledo RC, Jared C. Cutaneous granular glands and amphibian venoms. Comp Biochem Physiol. (1995) 111:1-29. doi: 10.1016/0300-9629(95)98515-I

7. Haslam IS, Roubos EW, Mangoni ML, Yoshizato K, Vaudry H, Kloepper JE, et al. From frog integument to human skin: dermatological perspectives from frog skin biology. Biol Rev. (2014) 89:618-55. doi: 10.1111/brv.12072

8. Yokoyama H, Kudo N, Todate M, Shimada Y, Suzuki M, Tamura K. Skin regeneration of amphibians: a novel model for skin regeneration as adults. Dev Growth Diff. (2018) 60:316-25. doi: 10.1111/dgd.12544

9. Larsen EH, Ramløv H. Role of cutaneous surface fluid in frog osmoregulation. Comp Biochem Physiol. (2013) 165:365-70. doi: 10.1016/j.cbpa.2013.04.005

10. Chinchar VG, Bryan L, Silphadaung U, Noga E, Wade D, RollinsSmith L. Inactivation of viruses infecting ectothermic animals by amphibian and piscine antimicrobial peptides. Virology (2004) 323:268-75. doi: 10.1016/j.virol.2004.02.029

11. Calhoun DM, Woodhams D, Howard C, LaFonte BE, Gregory JR, Johnson PT. Role of antimicrobial peptides in amphibian defence against trematode infection. EcoHealth (2016) 13:383-91. doi: 10.1007/s10393-016-1102-3

12. Sperandio B, Fischer N, Sansonetti PJ. Mucosal physical and chemical innate barriers: lessons from microbial evasion strategies. Sem Immunol. (2015) 27:111-8. doi: 10.1016/j.smim.2015.03.011

13. Ringø E, Løvmo L, Kristiansen M, Bakken Y, Salinas I, Myklebust R, et al. Lactic acid bacteria vs. pathogens in the gastrointestinal tract of fish: a review. Aqua Res. (2010) 41:451-67. doi: 10.1111/j.1365-2109.2009.02339.x

14. Plotkowski M, Bajolet-Laudinat O, Puchelle E. Cellular and molecular mechanisms of bacterial adhesion to respiratory mucosa. Euro Resp J. (1993) 6:903-16.

15. Kim JM, Eckmann L, Savidge TC, Lowe DC, Witthoft T, Kagnoff MF. Apoptosis of human intestinal epithelial cells after bacterial invasion. J Clin Invest. (1998) 102:1815-23. doi: 10.1172/JCI2466

16. Stuart SN, Chanson JS, Cox NA, Young BE, Rodrigues ASL, Fischman DL, et al. Status and trends of amphibian declines and extinctions worldwide. Science (2004) 306:1783-6. doi: 10.1126/science.1103538

17. Ramsey JP, Reinert LK, Harper LK, Woodhams DC, Rollins-Smith LA. Immune defences against Batrachochytrium dendrobatidis, a fungus linked to global amphibian declines, in the South African clawed frog, Xenopus laevis. Infect Immun. (2010) 78:3981-92. doi: 10.1128/IAI.00402-10

18. Jacques R, Edholm E-S, Jazz S, Odalys T-L, Francisco DJA. Xenopus-FV3 host-pathogen interactions and immune evasion. Virology (2017) 511:30919. doi: 10.1016/j.virol.2017.06.005

19. Daszak P, Cunningham AA, Hyatt AD. Infectious disease and amphibian population declines. Div Distrib. (2003) 9:141-50. doi: 10.1046/j.1472-4642.2003.00016.x

20. Skerratt LF, Berger L, Speare R, Cashins S, McDonald KR, Phillott $\mathrm{AD}$, et al. Spread of chytridiomycosis has caused the rapid global decline and extinction of frogs. EcoHealth (2007) 4:125-34. doi: 10.1007/s10393-007-0093-5

21. Alibardi L. Structural and immunocytochemical characterization of keratinization in vertebrate epidermis and epidermal derivatives. Int Rev Cyto (2006) 253:177-259. doi: 10.1016/S0074-7696(06)5 3005-0

22. Nokhbatolfoghahai M, Downie JR, Ogilvy V. Surface ciliation of anuran amphibian larvae: persistence to late stages in some species but not others. J Morph. (2006) 267:1248-56. doi: 10.1002/jmor.10469
23. Steinman RM. An electron microscopic study of ciliogenesis in developing epidermis and trachea in the embryo of Xenopus laevis. Am J Anat. (1968) 122:19-55. doi: 10.1002/aja.1001220103

24. Cone RA. Barrier properties of mucus. Adv Drug Del Rev. (2009) 61:75-85. doi: 10.1016/j.addr.2008.09.008

25. Stannard W, O'Callaghan C. Ciliary function and the role of cilia in clearance. J Aerosol Med. (2006) 19:110-5. doi: 10.1089/jam.2006.19.110

26. Bagnara JT, Taylor JD, Hadley ME. The dermal cromatophore unit. J Cell Biol. (1968) 38:67-79. doi: 10.1083/jcb.38.1.67

27. Azevedo RA, de Jesus Santana AS, de Brito-Gitirana L. Dermal collagen organization in Bufo ictericus and in Rana catesbeiana integument (Anuran, Amphibian) under the evaluation of laser confocal microscopy. Micron (2006) 37:223-8. doi: 10.1016/j.micron.2005.11.001

28. Denèfle JP, Zhu QL, Lechaire JP. Localization of fibronectin in the frog skin. Tiss Cell (1993) 25:87-102. doi: 10.1016/0040-8166(93)90066-T

29. Pelli AA, Cinelli LP, Mourão PAS, de Brito-Gitirana L. Glycosaminoglycans and glycoconjugates in the adult anuran integument (Lithobates catesbeianus). Micron (2010) 41:660-5. doi: 10.1016/j.micron.2010.03.001

30. Azevedo RA, Carvalho HF, de Brito-Gitirana L. Hyaluronan in the epidermal and the dermal extracellular matrix: its role in cutaneous hydric balance and integrity of anuran integument. Micron (2007) 38:607-10. doi: 10.1016/j.micron.2006.09.008

31. Ellison J, Garrod DR. Anchoring filaments of the amphibian epidermaldermal junction traverse the basal lamina entirely from the plasma membrane of hemidesmosomes to the dermis. J Cell Sci. (1984) 72:163-72.

32. Ramanayake T, Simon DA, Frelinger JG, Lord EM, Robert J. In vivo study of T-cell responses to skin alloantigens in Xenopus using a novel whole-mount immunohistology method. Transplantation (2007) 83:159-66. doi: 10.1097/01.tp.0000250562.35175.06

33. Castell-Rodríguez AE, Sampedro-Carrillo EA, Herrera-Enriquez MA, Rondán-Zárate A. Non-specific esterase-positive dendritic cells in epithelia of the frog Rana pipiens. Histochem J. (2001) 33:311-6. doi: 10.1023/A:1017985209296

34. Carrillo-Farga J, Castell A, Perez A, Rondan A. Langerhans-like cells in amphibian epidermis. J Anat. (1990) 172:39-45.

35. Marshall JS, Bienenstock J. The role of mast cells in inflammatory reactions of the airways, skin and intestine. Curr Opin Immunol. (1994) 6:853-9. doi: 10.1016/0952-7915(94)90004-3

36. Nedelkovska H, Edholm ES, Haynes N, Robert J. Effective RNAi-mediated $\beta 2$-microglobulin loss of function by transgenesis in Xenopus laevis. Biol Open (2013) 2:335-42. doi: 10.1242/bio.20133483

37. Nedelkovska H, Robert J. Hsp72 mediates stronger antigen-dependent nonclassical MHC class Ib anti-tumor responses than hsc73 in Xenopus laevis. Can Immun. (2013) 13:4.

38. Horton JD, Horton TL, Ritchie P, Varley CA. Skin xenograft rejection in Xenopus -immunohistology and effect of thymectomy. Transplantation (1992) 53:473-6. doi: 10.1097/00007890-199202010-00039

39. Holmes C, Balls M. In vitro studies on the control of myoepithelial cell contraction in the granular glands of Xenopus laevis skin. Gen Comp Endocrinol. (1978) 36:255-63. doi: 10.1016/0016-6480(78)90032-1

40. Brunetti AE, Hermida GN, Iurman MG, Faivovich J. Odorous secretions in anurans: morphological and functional assessment of serous glands as a source of volatile compounds in the skin of the treefrog Hypsiboas pulchellus (Amphibia: Anura: Hylidae). J Anat. (2016) 228:430-42. doi: $10.1111 /$ joa.12413

41. Mills JW, Prum BE. Morphology of the exocrine glands of the frog skin. Am J Anat. (1984) 171:91-106. doi: 10.1002/aja.1001710108

42. Sjöberg E, Flock AJC, Research T. Innervation of skin glands in the frog. Cell Tiss Res. (1976) 172:81-91. doi: 10.1007/BF00226050

43. Gammill WM, Fites JS, Rollins-Smith LA. Norepinephrine depletion of antimicrobial peptides from the skin glands of Xenopus laevis. Dev Comp Immunol. (2012) 37:19-27. doi: 10.1016/j.dci.2011.12.012

44. Lillywhite HB, Licht P. A comparative study of integumentary mucous secretions in amphibians. Comp Biochem Physiol. (1975) 51:937-41. doi: 10.1016/0300-9629(75)90077-8

45. Duellman WE, Trueb L. Biology of Amphibians: Johns Hopkins. London: University Press (1994). 
46. Lillywhite HB. Physiological correlates of basking in amphibians. Comp Biochem Physiol. (1975) 52:323-30. doi: 10.1016/S0300-9629(75)80095-8

47. Schumacher U, Adam E, Hauser F, Probst JC, Hoffmann W. Molecular anatomy of a skin gland: histochemical and biochemical investigations on the mucous glands of Xenopus laevis. J Histochem Cytochem. (1994) 42:57-65. doi: $10.1177 / 42.1 .7903329$

48. Engelhardt JF, Smith SS, Allen E, Yankaskas JR, Dawson DC, Wilson JM. Coupled secretion of chloride and mucus in skin of Xenopus laevis: possible role for CFTR. Am J Physiol. (1994) 267(2 Pt 1):C491-500. doi: 10.1152/ajpcell.1994.267.2.C491

49. Dubaissi E, Rousseau K, Hughes GW, Ridley C, Grencis RK, Roberts IS, et al. Functional characterization of the mucus barrier on the Xenopus tropicalis skin surface. PNAS (2018) 115:726-31. doi: 10.1073/pnas.1713539115

50. Barrionuevo JS. Skin structure variation in water frogs of the genus Telmatobius (Anura: Telmatobiidae). Salamandra (2017) 53:183-92.

51. Zasloff M. Antibiotic peptides as mediators of innate immunity. Curr Opin Immunol. (1992) 4:3-7. doi: 10.1016/0952-7915(92)90115-U

52. Soravia E, Martini G, Zasloff M. Antimicrobial properties of peptides from Xenopus granular gland secretions. FEBS Lett. (1988) 228:337-40. doi: 10.1016/0014-5793(88)80027-9

53. Antoniazzi MM, Neves PR, Mailho Fontana PL, Rodrigues MT, Jared C. Morphology of the parotoid macroglands in Phyllomedusa leaf frogs. J Zool. (2013) 291:42-50. doi: 10.1111/jzo.12044

54. Prates I, Antoniazzi MM, Sciani JM, Pimenta DC, Toledo LF, Haddad CF, et al. Skin glands, poison and mimicry in dendrobatid and leptodactylid amphibians. J Morph. (2012) 273:279-90. doi: 10.1002/jmor.11021

55. Rasit AH, Amirah MD, Sungif N, Zainudin R, Zulkarnaen M, Narihan A. The distribution and average size of granular gland in poisonous rock frog, Odorrana hosii. Malays Appl Biol J. (2018) 47:23-8.

56. Brizzi R, Delfino G, Pellegrini R. Specialized mucous glands and their possible adaptive role in the males of some species of Rana (Amphibia, Anura). J Morph. (2002) 254:328-41. doi: 10.1002/jmor.10039

57. Delfino G, Brizzi R, Alvarez BB, Gentili M. Granular cutaneous glands in the frog Physalaemus biligonigerus (Anura, Leptodactylidae): comparison between ordinary serous and 'inguinal' glands. Tiss Cell (1999) 31:576-86.

58. Rota E, Tanteri G, Montori G, Giachi F, Delfino G, Sever DM. Skin of the red eye tree frog Agalychnis Callidryas (Hylidae, Phyllomedusinae) contains lipid glands of the type described in the genus Phyllomedusa. Anat Rec. (2017) 300:503-6. doi: 10.1002/ar.23502

59. Seki T, Kikuyama S, Yanaihara NJC, Research T. Development of Xenopus laevis skin glands producing 5-hydroxytryptamine and caerulein. Cell Tiss Res. (1989) 258:483-9. doi: 10.1007/BF00218860

60. Angel R, Delfino G, Parra GJ. Ultrastructural patterns of secretory activity in poison cutaneous glands of larval and juvenile Dendrobates auratus (Amphibia, Anura). Toxicon (2003) 41:29-39. doi: 10.1016/S0041-0101(02)00206-4

61. Stynoski JL, O'Connell LAJZ. Developmental morphology of granular skin glands in pre-metamorphic egg-eating poison frogs. Zoomorph (2017) 136:219-24. doi: 10.1007/s00435-017-0344-0

62. Proksch E, Brandner JM, Jensen JM. The skin: an indispensable barrier. Exp Derm. (2008) 17:1063-72. doi: 10.1111/j.1600-0625.2008.00786.x

63. Matsui T, Amagai M. Dissecting the formation, structure and barrier function of the stratum corneum. Int Immunol. (2015) 27:269-80. doi: 10.1093/intimm/dxv013

64. Martinez-Palomo A, Erlij D, Bracho H. Localization of permeability barriers in the frog skin epithelium. J Cell Biol. (1971) 50:277-87. doi: $10.1083 /$ jcb.50.2.277

65. Chang DJ, Hwang YS, Cha SW, Chae JP, Hwang SH, Hahn JH, et al. Claudin 1 is required for the proper gastrulation in Xenopus laevis. Biochem Biophysl Res Comm. (2010) 397:75-81. doi: 10.1016/j.bbrc.2010.05.068

66. Levi G, Gumbiner B, Thiery JP. The distribution of E-cadherin during Xenopus laevis development. Development (1991) 111:159-69.

67. Warner AE. The role of gap junctions in amphibian development. J Emb Exp Morph. (1985) 89:365-80.

68. Shahin SH, Blankemeyer JT. Demonstration of gap junctions in frog skin epithelium. Am Phys Soc. (1989) 257:C658-64. doi: 10.1152/ajpcell.1989.257.4.C658
69. Suhrbier A, Garrod D. An investigation of the molecular components of desmosomes in epithelial cells of five vertebrates. J Cell Sci. (1986) 81:223-42.

70. Munoz WA, Kloc M, Cho K, Lee M, Hofmann I, Sater A, et al. Plakophilin-3 is required for late embryonic amphibian development, exhibiting roles in ectodermal and neural tissues. PLoS ONE (2012) 7:e34342. doi: 10.1371/journal.pone.0034342

71. Brandner JM, Poetzl C, Schmage P, Hauswirth U, Moll I. A (leaky?) barrier: tight junction proteins in skin diseases. Drug Disc Tod. (2008) 5:e39-45. doi: 10.1016/j.ddmec.2008.04.007

72. Kwong RW, Kumai Y, Perry SF. Evidence for a role of tight junctions in regulating sodium permeability in zebrafish (Danio rerio) acclimated to ion-poor water. J Comp Physiol. (2013) 183:203-13. doi: 10.1007/s00360-012-0700-9

73. Kirschner N, Brandner JM. Barriers and more: functions of tight junction proteins in the skin. Ann N Y Acad Sci. (2012) 1257:158-66. doi: $10.1111 / j .1749-6632.2012 .06554 . x$

74. Ribet D, Cossart P. How bacterial pathogens colonize their hosts and invade deeper tissues. Micro Infec. (2015) 17:173-83. doi: 10.1016/j.micinf.2015.01.004

75. Ferreira KT, Hill BS. The effect of low external $\mathrm{pH}$ on properties of the paracellular pathway and junctional structure in isolated frog skin. J Physiol. (1982) 332:59-67. doi: 10.1113/jphysiol.1982.sp014400

76. Furuse M, Hata M, Furuse K, Yoshida Y, Haratake A, Sugitani Y, et al. Claudin-based tight junctions are crucial for the mammalian epidermal barrier: a lesson from claudin-1-deficient mice. J Cell Biol. (2002) 156:1099111. doi: $10.1083 /$ jcb. 200110122

77. Ohmer M, Cramp R, J. M. Russo C, White C, Franklin C. Skin sloughing in susceptible and resistant amphibians regulates infection with a fungal pathogen. Sci Rep. (2017) 7:3529. doi: 10.1038/s41598-017-03605-Z

78. Ohmer MEB, Cramp RL, White CR, Franklin CE. Skin sloughing rate increases with chytrid fungus infection load in a susceptible amphibian. Func Ecol. (2015) 29:674-82. doi: 10.1111/1365-2435.12370

79. Cramp RL, McPhee RK, Meyer EA, Ohmer ME, Franklin CE. First line of defence: the role of sloughing in the regulation of cutaneous microbes in frogs. Conserv Physiol. (2014) 2:cou012. doi: 10.1093/conphys/cou012

80. Dubaissi E, Rousseau K, Lea R, Soto X, Nardeosingh S, Schweickert A, et al. A secretory cell type develops alongside multiciliated cells, ionocytes and goblet cells, and provides a protective, antiinfective function in the frog embryonic mucociliary epidermis. Development (2014) 141:1514-25. doi: $10.1242 /$ dev. 102426

81. Walentek P, Bogusch S, Thumberger T, Vick P, Dubaissi E, Beyer T, et al. A novel serotonin-secreting cell type regulates ciliary motility in the mucociliary epidermis of Xenopus tadpoles. Development (2014) 141:152633. doi: $10.1242 / \mathrm{dev} .102343$

82. Mall MA. Role of cilia, mucus, and airway surface liquid in mucociliary dysfunction: lessons from mouse models. J Aer Med Pul Drug Del. (2008) 21:13-24. doi: 10.1089/jamp.2007.0659

83. Hancock RE, Scott MG. The role of antimicrobial peptides in animal defences. PNAS (2000) 97:8856-61. doi: 10.1073/pnas.97.1 6.8856

84. Cuesta A, Meseguer J, Esteban MA. The antimicrobial peptide hepcidin exerts an important role in the innate immunity against bacteria in the bony fish gilthead seabream. Mol Immunol. (2008) 45:2333-42. doi: 10.1016/j.molimm.2007.11.007

85. Kress E, Merres J, Albrecht LJ, Hammerschmidt S, Pufe T, Tauber SC, et al. CRAMP deficiency leads to a pro-inflammatory phenotype and impaired phagocytosis after exposure to bacterial meningitis pathogens. Cell Comm Sign. (2017) 15:32. doi: 10.1186/s12964-017-0190-1

86. van Dijk A, van Eldik M, Veldhuizen EJ, Tjeerdsma-van Bokhoven HL, de Zoete MR, Bikker FJ, et al. Immunomodulatory and anti-inflammatory activities of chicken Cathelicidin-2 derived peptides. PLoS ONE (2016) 11:e0147919. doi: 10.1371/journal.pone.0147919

87. Konig E, Bininda-Emonds OR, Shaw C. The diversity and evolution of anuran skin peptides. Peptides (2015) 63:96-117. doi: 10.1016/j.peptides.2014.11.003

88. Ladram A, Nicolas P. Antimicrobial peptides from frog skin: biodiversity and therapeutic promises. Front Biosci. (2016) 21:1341-71. doi: 10.2741/4461 
89. Mesquita AFC, Lambertini C, Lyra M, Malagoli LR, James TY, Toledo LF, et al. Low resistance to chytridiomycosis in direct-developing amphibians. Sci Rep. (2017) 7:16605. doi: 10.1038/s41598-017-16425-y

90. Brenes R, Gray MJ, Waltzek TB, Wilkes RP, Miller DL. Transmission of ranavirus between ectothermic vertebrate hosts. PLoS ONE (2014) 9:e92476. doi: 10.1371/journal.pone.0092476

91. Braff MH, Bardan A, Nizet V, Gallo RL. Cutaneous defence mechanisms by antimicrobial peptides. J Invest Derm. (2005) 125:9-13. doi: 10.1111/j.0022-202X.2004.23587.x

92. Duplantier AJ, van Hoek ML. The human cathelicidin antimicrobial peptide LL-37 as a potential treatment for polymicrobial infected wounds. Front Immunol. (2013) 4:143. doi: 10.3389/fimmu.2013.00143

93. Lande R, Chamilos G, Ganguly D, Demaria O, Frasca L, Durr S, et al. Cationic antimicrobial peptides in psoriatic skin cooperate to break innate tolerance to self-DNA. Euro J Immunol. (2015) 45:203-13. doi: 10.1002/eji.201344277

94. Yamasaki K, Di Nardo A, Bardan A, Murakami M, Ohtake T, Coda A, et al. Increased serine protease activity and cathelicidin promotes skin inflammation in rosacea. Nat Med. (2007) 13:975-80. doi: 10.1038/nm1616

95. Wang G, Li X, Wang Z. APD3: the antimicrobial peptide database as a tool for research and education. Nuc Acids Res. (2016) 44:D1087-93. doi: 10.1093/nar/gkv1278

96. Rollins-Smith LA, Reinert LK, Miera V, Conlon JM. Antimicrobial peptide defences of the Tarahumara frog, Rana tarahumarae. Biochem Biophysical Res Comm. (2002) 297:361-7. doi: 10.1016/S0006-291X(02)02217-9

97. Hancock RE, Sahl HG. Antimicrobial and host-defence peptides as new anti-infective therapeutic strategies. Nat Biotech. (2006) 24:1551-7. doi: $10.1038 /$ nbt1267

98. Rollins-Smith LA, Reinert LK, O'Leary CJ, Houston LE, Woodhams DC. Antimicrobial Peptide defences in amphibian skin. Integ Comp Biol. (2005) 45:137-42. doi: 10.1093/icb/45.1.137

99. Zasloff M. Magainins, a class of antimicrobial peptides from Xenopus skin: isolation, characterization of two active forms, and partial cDNA sequence of a precursor. PNAS (1987) 84:5449-53. doi: 10.1073/pnas.84.15.5449

100. Mechkarska M, Ahmed E, Coquet L, Leprince J, Jouenne T, Vaudry H, et al. Antimicrobial peptides with therapeutic potential from skin secretions of the Marsabit clawed frog Xenopus borealis (Pipidae). Comp Biochem Physiol Tox Pharm. (2010) 152:467-72. doi: 10.1016/j.cbpc.2010.07.007

101. Simmaco M, Mignogna G, Barra D, Bossa F. Antimicrobial peptides from skin secretions of Rana esculenta. Molecular cloning of cDNAs encoding esculentin and brevinins and isolation of new active peptides. J Biol Chem. (1994) 269:11956-61.

102. Mor A, Nicolas P. Isolation and structure of novel defensive peptides from frog skin. Euro J Biochem. (1994) 219:145-54. doi: 10.1111/j.1432-1033.1994.tb19924.x

103. Hao X, Yang H, Wei L, Yang S, Zhu W, Ma D, et al. Amphibian cathelicidin fills the evolutionary gap of cathelicidin in vertebrate. Amino Acids (2012) 43:677-85. doi: 10.1007/s00726-011-1116-7

104. Matthijs S, Ye L, Stijlemans B, Cornelis P, Bossuyt F, Roelants K. Low structural variation in the host-defence peptide repertoire of the dwarf clawed frog Hymenochirus boettgeri (Pipidae). PLoS ONE (2014) 9:e86339. doi: 10.1371/journal.pone.0086339

105. Ludtke SJ, He K, Heller WT, Harroun TA, Yang L, Huang HW. Membrane pores induced by magainin. Biochemistry (1996) 35:13723-8. doi: 10.1021/bi9620621

106. Zasloff M. Antimicrobial peptides of multicellular organisms. Nature (2002) 415:389-95. doi: 10.1038/415389a

107. Pino-Angeles A, Leveritt JM III, Lazaridis T. Pore structure and synergy in antimicrobial peptides of the magainin family. PLoS Comp Biol. (2016) 12:e1004570. doi: 10.1371/journal.pcbi.1004570

108. Haney EF, Hunter HN, Matsuzaki K, Vogel HJ. Solution NMR studies of amphibian antimicrobial peptides: linking structure to function? Biochim Biophys Acta (2009) 1788:1639-55. doi: 10.1016/j.bbamem.2009.01.002

109. Lan Y, Ye Y, Kozlowska J, Lam JK, Drake AF, Mason AJ. Structural contributions to the intracellular targeting strategies of antimicrobial peptides. Biochim Biophys Acta (2010) 1798:1934-43. doi: 10.1016/j.bbamem.2010.07.003
110. Bechinger B, Zasloff M, Opella SJ. Structure and orientation of the antibiotic peptide magainin in membranes by solid-state nuclear magnetic resonance spectroscopy. Prot Sci. (1993) 2:2077-84. doi: 10.1002/pro.5560021208

111. Imura Y, Choda N, Matsuzaki K. Magainin 2 in action: distinct modes of membrane permeabilization in living bacterial and mammalian cells. Biophys J. (2008) 95:5757-65. doi: 10.1529/biophysj.108.133488

112. Loffredo MR, Ghosh A, Harmouche N, Casciaro B, Luca V, Bortolotti A, et al. Membrane perturbing activities and structural properties of the frog-skin derived peptide Esculentin-1a(1-21)NH2 and its Diastereomer Esc(1-21)1c: correlation with their antipseudomonal and cytotoxic activity. Biochim Biophys Acta (2017) 1859:2327-39. doi: 10.1016/j.bbamem.2017.09.009

113. Hasan M, Karal MAS, Levadnyy V, Yamazaki M. Mechanism of initial stage of pore formation induced by antimicrobial peptide Magainin 2. Langmuir (2018) 34:3349-62. doi: 10.1021/acs.langmuir.7b04219

114. Manzo G, Casu M, Rinaldi AC, Montaldo NP, Luganini A, Gribaudo G, et al. Folded structure and insertion depth of the frog-skin antimicrobial Peptide esculentin-1b(1-18) in the presence of differently charged membranemimicking micelles. J Nat Prod. (2014) 77:2410-7. doi: 10.1021/np5004406

115. Harmouche N, Bechinger B. Lipid-mediated interactions between the antimicrobial peptides Magainin 2 and PGLa in bilayers. Biophys J. (2018) 115:1033-44. doi: 10.1016/j.bpj.2018.08.009

116. Munster C, Spaar A, Bechinger B, Salditt T. Magainin 2 in phospholipid bilayers: peptide orientation and lipid chain ordering studied by X-ray diffraction. Biochim Biophys Acta (2002) 1562:37-44. doi: 10.1016/S0005-2736(02)00357-7

117. Luca V, Stringaro A, Colone M, Pini A, Mangoni ML. Esculentin(121), an amphibian skin membrane-active peptide with potent activity on both planktonic and biofilm cells of the bacterial pathogen Pseudomonas aeruginosa. Cell Mol Life Sci. (2013) 70:2773-86. doi: 10.1007/s00018-013-1291-7

118. Conlon JM. The contribution of skin antimicrobial peptides to the system of innate immunity in anurans. Cell Tiss Res. (2011) 343:201-12. doi: 10.1007/s00441-010-1014-4

119. Rollins-Smith LA, Reinert LK, Burrowes PA. Coqui frogs persist with the deadly chytrid fungus despite a lack of defensive antimicrobial peptides. Dis Aquatic Org. (2015) 113:81-3. doi: 10.3354/dao02823

120. Lorin C, Saidi H, Belaid A, Zairi A, Baleux F, Hocini H, et al. The antimicrobial peptide dermaseptin S4 inhibits HIV-1 infectivity in vitro. Virology (2005) 334:264-75. doi: 10.1016/j.virol.2005.02.002

121. Albiol Matanic VC, Castilla V. Antiviral activity of antimicrobial cationic peptides against Junin virus and herpes simplex virus. Int J Antimicrob Agents (2004) 23:382-9. doi: 10.1016/j.ijantimicag.2003.07.022

122. Schadich E, Mason D, Cole AL. Neutralization of bacterial endotoxins by frog antimicrobial peptides. Microbiol Immunol. (2013) 57:159-61. doi: 10.1111/1348-0421.12012

123. Huang L, Li J, Anboukaria H, Luo Z, Zhao M, Wu H. Comparative transcriptome analyses of seven anurans reveal functions and adaptations of amphibian skin. Sci Rep. (2016) 6:24069. doi: 10.1038/srep 24069

124. Fan W, Jiang Y, Zhang M, Yang D, Chen Z, Sun H, et al. Comparative transcriptome analyses reveal the genetic basis underlying the immune function of three amphibians' skin. PLOS ONE (2017) 12:e0190023. doi: 10.1371/journal.pone.0190023

125. Lau Q, Igawa T, Minei R, Kosch TA, Satta Y. Transcriptome analyses of immune tissues from three Japanese frogs (genus Rana ) reveals their utility in characterizing major histocompatibility complex class II. BMC Genomics (2017) 18:994. doi: 10.1186/s12864-017-4404-0

126. Robertson LS, Cornman RS. Transcriptome resources for the frogs Lithobates clamitans and Pseudacris regilla, emphasizing antimicrobial peptides and conserved loci for phylogenetics. Mol Ecol Resour (2014) 14:178-83. doi: 10.1111/1755-0998.12164

127. Qiao L, Yang W, Fu J, Song Z. Transcriptome profile of the green odorous frog (Odorrana margaretae). PLoS ONE (2013) 8:e75211. doi: 10.1371/journal.pone.0075211

128. Woodhams DC, Bell SC, Bigler L, Caprioli RM, Chaurand P, Lam BA, et al. Life history linked to immune investment in developing amphibians. Conserv Physiol. (2016) 4:cow025. doi: 10.1093/conphys/cow025 
129. Mangoni ML, Miele R, Renda TG, Barra D, Simmaco M. The synthesis of antimicrobial peptides in the skin of Rana esculenta is stimulated by microorganisms. FASEB J. (2001) 15:1431-2. doi: 10.1096/fj.00-0695fje

130. Wada A, Ogushi K, Kimura T, Hojo H, Mori N, Suzuki S, et al. Helicobacter pylori-mediated transcriptional regulation of the human betadefensin 2 gene requires NF-kappaB. Cell Microbiol. (2001) 3:115-23. doi: 10.1046/j.1462-5822.2001.00096.x

131. Yang W, Molenaar A, Kurts-Ebert B, Seyfert HM. NF-kappaB factors are essential, but not the switch, for pathogen-related induction of the bovine beta-defensin 5-encoding gene in mammary epithelial cells. Mol Immunol. (2006) 43:210-25. doi: 10.1016/j.molimm.2005.02.003

132. Minakhina S, Steward R. Nuclear factor-kappa B pathways in Drosophila. Oncogene (2006) 25:6749-57. doi: 10.1038/sj.onc.1209940

133. Xi L, Wang C, Chen P, Yang Q, Hu R, Zhang H, et al. Expressions of IL6, TNF-alpha and NF-kappaB in the skin of Chinese brown frog (Rana dybowskii). Eur J Histochem. (2017) 61:2834. doi: 10.4081/ejh.2017.2834

134. Kwon SY, Carlson BA, Park JM, Lee BJ. Structural organization and expression of the gaegurin 4 gene of Rana rugosa. Biochim Biophys Acta (2000) 1492:185-90. doi: 10.1016/S0167-4781(00)00082-8

135. Miele R, Bjorklund G, Barra D, Simmaco M, Engstrom Y. Involvement of Rel factors in the expression of antimicrobial peptide genes in amphibia. Eur J Biochem. (2001) 268:443-9. doi: 10.1046/j.1432-1033.2001.01908.x

136. Roelants K, Fry BG, Ye L, Stijlemans B, Brys L, Kok P, et al. Origin and functional diversification of an amphibian defence peptide arsenal. PLoS Genet. (2013) 9:e1003662. doi: 10.1371/journal.pgen.1003662

137. Holthausen DJ, Lee SH, Kumar VT, Bouvier NM, Krammer F, Ellebedy $\mathrm{AH}$, et al. An amphibian host defence peptide is virucidal for Human H1 hemagglutinin-bearing influenza viruses. Immunity (2017) 46:587-95. doi: 10.1016/j.immuni.2017.03.018

138. Thwaite JE, Humphrey S, Fox MA, Savage VL, Laws TR, Ulaeto DO, et al. The cationic peptide magainin II is antimicrobial for Burkholderia cepacia-complex strains. J Med Microbiol. (2009) 58(Pt 7):9239. doi: 10.1099/jmm.0.008128-0

139. Talbott K, Wolf TM, Sebastian P, Abraham M, Bueno I, McLaughlin M, et al. Factors influencing detection and co-detection of Ranavirus and Batrachochytrium dendrobatidis in Midwestern North American anuran populations. Dis Aquatic Org. (2018) 128:93-103. doi: 10.3354/dao03217

140. Mor A, Hani K, Nicolas P. The vertebrate peptide antibiotics dermaseptins have overlapping structural features but target specific microorganisms. $J$ Biol Chem. (1994) 269:31635-41.

141. Schadich E. Skin peptide activities against opportunistic bacterial pathogens of the african clawed frog (Xenopus laevis) and three litoria frogs. J Herp. (2009) 43:173-83. doi: 10.1670/08-113R1.1

142. Rollins-Smith LA, Doersam JK, Longcore JE, Taylor SK, Shamblin JC, Carey C, et al. Antimicrobial peptide defences against pathogens associated with global amphibian declines. Dev Comp Immunol. (2002) 26:63-72. doi: 10.1016/S0145-305X(01)00041-6

143. Eley A, Ibrahim M, Kurdi SE, Conlon JM. Activities of the frog skin peptide, ascaphin- 8 and its lysine-substituted analogs against clinical isolates of extended-spectrum beta-lactamase (ESBL) producing bacteria. Peptides (2008) 29:25-30. doi: 10.1016/j.peptides.2007.10.026

144. Sousa JC, Berto RF, Gois EA, Fontenele-Cardi NC, Honorio JE, Jr., Konno K, et al. Leptoglycin: a new Glycine/Leucine-rich antimicrobial peptide isolated from the skin secretion of the South American frog Leptodactylus pentadactylus (Leptodactylidae). Toxicon (2009) 54:23-32. doi: 10.1016/j.toxicon.2009.03.011

145. Conlon JM, Ahmed E, Coquet L, Jouenne T, Leprince J, Vaudry H, et al. Peptides with potent cytolytic activity from the skin secretions of the North American leopard frogs, Lithobates blairi and Lithobates yavapaiensis. Toxicon (2009) 53:699-705. doi: 10.1016/j.toxicon.2009.02.018

146. Davidson C, Benard MF, Shaffer HB, Parker JM, O'Leary C, Conlon JM, et al. Effects of chytrid and carbaryl exposure on survival, growth and skin peptide defences in foothill yellow-legged frogs. Enviro Sci Technol. (2007) 41:1771-6. doi: 10.1021/es0611947

147. Rollins-Smith LA, Woodhams DC, Reinert LK, Vredenburg VT, Briggs CJ, Nielsen PF, et al. Antimicrobial peptide defences of the mountain yellow-legged frog (Rana muscosa). Dev Comp Immunol. (2006) 30:831-42. doi: $10.1016 /$ j.dci.2005.10.005
148. Conlon JM, Reinert LK, Mechkarska M, Prajeep M, Meetani MA, Coquet L, et al. Evaluation of the skin peptide defences of the Oregon spotted frog Rana pretiosa against infection by the chytrid fungus Batrachochytrium dendrobatidis. J Chem Ecol. (2013) 39:797-805. doi: 10.1007/s10886-013-0294-z

149. Rollins-Smith L. The role of amphibian antimicrobial peptides in protection of amphibians from pathogens linked to global amphibian declines. Biochim et Biophys Acta (2009) 1788:1593-9. doi: 10.1016/j.bbamem.2009.03.008

150. Emerson H, Charles N. "Red-leg" an infectious disease of frogs. J Exp Med. (1905) 7:32-58.

151. Rollins-Smith LA, Conlon JM. Antimicrobial peptide defences against chytridiomycosis, an emerging infectious disease of amphibian populations. Dev Comp Immunol. (2005) 29:589-98. doi: 10.1016/j.dci.2004.11.004

152. Melzer S, Bishop PJ. Skin peptide defences of New Zealand frogs against chytridiomycosis. Anim Conserv. (2010) 13:44-52. doi: $10.1111 / \mathrm{j} .1469-1795.2009 .00340 . \mathrm{x}$

153. Nizet V, Ohtake T, Lauth X, Trowbridge J, Rudisill J, Dorschner RA, et al. Innate antimicrobial peptide protects the skin from invasive bacterial infection. Nature (2001) 414:454-7. doi: 10.1038/35106587

154. Gregorio J, Meller S, Conrad C, Di Nardo A, Homey B, Lauerma A, et al. Plasmacytoid dendritic cells sense skin injury and promote wound healing through type I interferons. J Exp Med. (2010) 207:2921-30. doi: $10.1084 /$ jem.20101102

155. Mangoni ML, McDermott AM, Zasloff M. Antimicrobial peptides and wound healing: biological and therapeutic considerations. Exp Dermatol. (2016) 25:167-73. doi: 10.1111/exd.12929

156. Niyonsaba F, Kiatsurayanon C, Chieosilapatham P, Ogawa H. Friends or Foes? Host defence (antimicrobial) peptides and proteins in human skin diseases. Exp Dermatol. (2017) 26:989-98. doi: 10.1111/exd.13314

157. Wu J, Yang J, Wang X, Wei L, Mi K, Shen Y, et al. A frog cathelicidin peptide effectively promotes cutaneous wound healing in mice. Biochem J. (2018):2785-99. doi: 10.1042/BCJ20180286

158. Di Grazia A, Cappiello F, Imanishi A, Mastrofrancesco A, Picardo M, Paus R, et al. The frog skin-derived antimicrobial peptide Esculentin-1a(1-21)NH2 promotes the migration of human $\mathrm{HaCaT}$ Keratinocytes in an EGF receptordependent manner: a novel promoter of human skin wound healing? PLoS ONE (2015) 10:e0128663. doi: 10.1371/journal.pone.0128663

159. Durr UH, Sudheendra US, Ramamoorthy A. LL-37, the only human member of the cathelicidin family of antimicrobial peptides. Biochim Biophys Acta (2006) 1758:1408-25. doi: 10.1016/j.bbamem.2006.03.030

160. Selsted ME, Ouellette AJ. Mammalian defensins in the antimicrobial immune response. Nat Immunol. (2005) 6:551-7. doi: 10.1038/ni1206

161. Hancock RE, Haney EF, Gill EE. The immunology of host defence peptides: beyond antimicrobial activity. Nat Rev Immunol. (2016) 16:321-34. doi: 10.1038/nri.2016.29

162. Marenah L, Flatt PR, Orr DF, Shaw C, Abdel-Wahab YH. Characterization of naturally occurring peptides in the skin secretion of Rana pipiens frog reveal pipinin-1 as the novel insulin-releasing agent. J Pep Res. (2005) 66:204-10. doi: 10.1111/j.1399-3011.2005.00287.x

163. Ojo OO, Conlon JM, Flatt PR, Abdel-Wahab YH. Frog skin peptides (tigerinin-1R, magainin-AM1, AM2, CPF-AM1, and PGla-AM1) stimulate secretion of glucagon-like peptide 1 (GLP-1) by GLUTag cells. Biochem Biophys Res Com. (2013) 431:14-8. doi: 10.1016/j.bbrc.2012.12.116

164. Liu H, Duan Z, Tang J, Lv Q, Rong M, Lai R. A short peptide from frog skin accelerates diabetic wound healing. FEBS J. (2014) 281:4633-43. doi: 10.1111/febs. 12968

165. Insuela DBR, Carvalho VF. Glucagon and glucagon-like peptide-1 as novel anti-inflammatory and immunomodulatory compounds. Euro J Pharm. (2017) 812:64-72. doi: 10.1016/j.ejphar.2017.07.015

166. Bechinger B, Lohner K. Detergent-like actions of linear amphipathic cationic antimicrobial peptides. Biochim Biophys Acta (2006) 1758:1529-39. doi: 10.1016/j.bbamem.2006.07.001

167. Daly JW. Thirty years of discovering arthropod alkaloids in amphibian skin. J Nat Prod. (1998) 61:162-72. doi: 10.1021/np970460e

168. Daly JW, Myers CW, Whittaker N. Further classification of skin alkaloids from neotropical poison frogs (Dendrobatidae), with a general survey of toxic/noxious substances in the amphibia. Toxicon (1987) 25:1023-95. doi: 10.1016/0041-0101(87)90265-0 
169. Daly JW, Spande TF, Garraffo HM. Alkaloids from amphibian skin: a tabulation of over eight-hundred compounds. J Nat Prod. (2005) 68:1556-75. doi: $10.1021 / \mathrm{np} 0580560$

170. Rodríguez A, Poth D, Schulz S, Vences M. Discovery of skin alkaloids in a miniaturized eleutherodactylid frog from Cuba. Biol Lett. (2011) 7:414-8. doi: 10.1098/rsbl.2010.0844

171. Daly JW, Noimai N, Kongkathip B, Kongkathip N, Wilham JM, Garraffo $\mathrm{HM}$, et al. Biologically active substances from amphibians: preliminary studies on anurans from twenty-one genera of Thailand. Toxicon (2004) 44:805-15. doi: 10.1016/j.toxicon.2004.08.016

172. Hovey KJ, Seiter EM, Johnson EE, Saporito RA. Sequestered alkaloid defences in the Dendrobatid poison frog oophaga pumilio provide variable protection from microbial pathogens. J Chem Ecol. (2018) 44:312-25. doi: 10.1007/s10886-018-0930-8

173. Daly JW. Ernest Guenther award in chemistry of natural products. Amphibian skin: a remarkable source of biologically active arthropod alkaloids. J Med Chem. (2003) 46:445-52. doi: 10.1021/jm0204845

174. Fritz JH, Le Bourhis L, Magalhaes JG, Philpott DJ. Innate immune recognition at the epithelial barrier drives adaptive immunity: APCs take the back seat. Trends Immunol. (2008) 29:41-9. doi: 10.1016/j.it.2007.10.002

175. Gunther J, Seyfert HM. The first line of defence: insights into mechanisms and relevance of phagocytosis in epithelial cells. Sem Immunopathol. (2018) 40:555-65. doi: 10.1007/s00281-018-0701-1

176. Brubaker SW, Bonham KS, Zanoni I, Kagan JC. Innate immune pattern recognition: a cell biological perspective. Ann Rev Immunol. (2015) 33:25790. doi: 10.1146/annurev-immunol-032414-112240

177. Alvarez K, Vasquez G. Damage-associated molecular patterns and their role as initiators of inflammatory and auto-immune signals in systemic lupus erythematosus. Int Rev Immunol. (2017) 36:259-70. doi: 10.1080/08830185.2017.1365146

178. Cario E, Podolsky DK. Intestinal epithelial TOLLerance versus inTOLLerance of commensals. Mol Immunol. (2005) 42:887-93. doi: 10.1016/j.molimm.2004.12.002

179. Hirata Y, Broquet AH, Menchen L, Kagnoff MF. Activation of innate immune defence mechanisms by signalling through RIGI/IPS-1 in intestinal epithelial cells. J Immunol. (2007) 179:5425-32. doi: 10.4049/jimmunol.179.8.5425

180. Lei-Leston AC, Murphy AG, Maloy KJ. Epithelial cell inflammasomes in intestinal immunity and inflammation. Front Immunol. (2017) 8:1168. doi: 10.3389/fimmu.2017.01168

181. Wendel ES, Yaparla A, Melnyk MLS, Koubourli DV, Grayfer L. Amphibian (Xenopus laevis) tadpoles and adult frogs differ in their use of expanded repertoires of type I and type III interferon cytokines. Viruses (2018) 10:10070372. doi: 10.3390/v10070372

182. Xiao XH, Miao HM, Xu YG, Zhang JY, Chai LH, Xu JJ. Analysis of skin and secretions of Dybowski's frogs (Rana dybowskii) exposed to Staphylococcus aureus or Escherichia coli identifies immune response proteins. Vet J. (2014) 200:127-32. doi: 10.1016/j.tvjl.2014.01.011

183. Zhao F, Yan C, Wang X, Yang Y, Wang G, Lee W, et al. Comprehensive transcriptome profiling and functional analysis of the frog (Bombina maxima) immune system. DNA Res. (2014) 21:1-13. doi: 10.1093/dnares/dst035

184. Roach JC, Glusman G, Rowen L, Kaur A, Purcell MK, Smith KD, et al. The evolution of vertebrate Toll-like receptors. PNAS (2005) 102:9577-82. doi: 10.1073/pnas.0502272102

185. Song X, Jin P, Qin S, Chen L, Ma F. The evolution and origin of animal Toll-like receptor signalling pathway revealed by networklevel molecular evolutionary analyses. PLOS ONE (2012) 7:e51657. doi: 10.1371/journal.pone.0051657

186. Ishii A, Kawasaki M, Matsumoto M, Tochinai S, Seya T. Phylogenetic and expression analysis of amphibian Xenopus Toll-like receptors. Immunogen (2007) 59:281-93. doi: 10.1007/s00251-007-0193-y

187. Lau Q, Igawa T, Kosch TA, Satta Y. Selective constraint acting on TLR2 and TLR4 genes of Japanese Rana frogs. PeerJ. (2018) 6:e4842. doi: $10.7717 /$ peerj. 4842

188. Rauta PR, Samanta M, Dash HR, Nayak B, Das S. Toll-like receptors (TLRs) in aquatic animals: signalling pathways, expressions and immune responses. Immunol Lett. (2014) 158:14-24. doi: 10.1016/j.imlet.201 3.11 .013

189. Majer O, Liu B, Barton GM. Nucleic acid-sensing TLRs: trafficking and regulation. Curr Opin Immunol. (2017) 44:26-33. doi: 10.1016/j.coi.2016.10.003

190. Nikolaeva S, Bachteeva V, Fock E, Herterich S, Lavrova E, Borodkina A, et al Frog urinary bladder epithelial cells express TLR4 and respond to bacterial LPS by increase of iNOS expression and L-arginine uptake. Am J Physiol. (2012) 303:R1042-52. doi: 10.1152/ajpregu.00045.2012

191. Chow KT, Gale M Jr, Loo YM. RIG-I and other RNA sensors in antiviral immunity. Ann Rev Immunol. (2018) 36:667-94. doi: 10.1146/annurev-immunol-042617-053309

192. Saito T, Hirai R, Loo YM, Owen D, Johnson CL, Sinha SC, et al. Regulation of innate antiviral defences through a shared repressor domain in RIG-I and LGP2. PNAS (2007) 104:582-7. doi: 10.1073/pnas.0606699104

193. Zou J, Chang M, Nie P, Secombes CJ. Origin and evolution of the RIG-I like RNA helicase gene family. BMC Evol Biol. (2009) 9:85. doi: 10.1186/1471-2148-9-85

194. Davis BK, Wen H, Ting JP. The inflammasome NLRs in immunity, inflammation, and associated diseases. Ann Rev Immunol. (2011) 29:707-35. doi: 10.1146/annurev-immunol-031210-101405

195. Boudinot P, Zou J, Ota T, Buonocore F, Scapigliati G, Canapa A, et al. A tetrapod-like repertoire of innate immune receptors and effectors for coelacanths. J Exp Zool. (2014) 322:415-37. doi: 10.1002/jez.b.22559

196. Laing KJ, Purcell MK, Winton JR, Hansen JD. A genomic view of the NODlike receptor family in teleost fish: identification of a novel NLR subfamily in zebrafish. BMC Evol Biol. (2008) 8:42. doi: 10.1186/1471-2148-8-42

197. Perez-Iglesias JM, Soloneski S, Nikoloff N, Natale GS, Larramendy ML. Toxic and genotoxic effects of the imazethapyr-based herbicide formulation Pivot $\mathrm{H}(\mathrm{R})$ on montevideo tree frog Hypsiboas pulchellus tadpoles (Anura, Hylidae). Ecotox Environ Safety (2015) 119:15-24. doi: 10.1016/j.ecoenv.2015.04.045

198. Tennessen JB, Parks SE, Langkilde T. Traffic noise causes physiological stress and impairs breeding migration behaviour in frogs. Conserv Physiol. (2014) 2:cou032. doi: 10.1093/conphys/cou032

199. Wang GD, Zhang BL, Zhou WW, Li YX, Jin JQ, Shao Y, et al. Selection and environmental adaptation along a path to speciation in the Tibetan frog Nanorana parkeri. PNAS (2018) 115:E5056-e65. doi: $10.1073 /$ pnas.1716257115

200. Matutte B, Storey KB, Knoop FC, Conlon JM. Induction of synthesis of an antimicrobial peptide in the skin of the freeze-tolerant frog, Rana sylvatica, in response to environmental stimuli. FEBS Lett. (2000) 483:135-8. doi: 10.1016/S0014-5793(00)02102-5

201. Katzenback BA, Holden HA, Falardeau J, Childers C, Hadj-Moussa H, Avis TJ, et al. Regulation of the Rana sylvatica brevinin-1SY antimicrobial peptide during development and in dorsal and ventral skin in response to freezing, anoxia and dehydration. J Exp Biol. (2014) 217(Pt 8):1392-401. doi: $10.1242 /$ jeb.092288

202. Wullaert A, Bonnet MC, Pasparakis M. NF- $\kappa$ B in the regulation of epithelial homeostasis and inflammation. Cell Res. (2010) 21:146. doi: 10.1038/cr.2010.175

203. Sonna LA, Fujita J, Gaffin SL, Lilly CM. Invited review: effects of heat and cold stress on mammalian gene expression. J App Physiol. (2002) 92:1725-42. doi: 10.1152/japplphysiol.01143.2001

204. Ketola-Pirie CA, Atkinson BG. Cold- and heat-shock induction of new gene expression in cultured amphibian cells. Can J Biochem Cell Biol. (1983) 61:462-71. doi: 10.1139/o83-062

205. Krynak KL, Burke DJ, Benard MF. Larval environment alters amphibian immune defences differentially across life stages and populations. PLOS ONE (2015) 10:e0130383. doi: 10.1371/journal.pone.0130383

206. Gilbertson MK, Haffner GD, Drouillard KG, Albert A, Dixon B Immunosuppression in the northern leopard frog (Rana pipiens) induced by pesticide exposure. Enviro Tox Chem. (2003) 22:101-10. doi: 10.1002/etc.5620220113

207. Quaranta A, Bellantuono V, Cassano G, Lippe C. Why amphibians are more sensitive than mammals to xenobiotics. PLoS ONE (2009) 4:e7699. doi: 10.1371/journal.pone.0007699 
208. Blaustein AR, Romansic JM, Kiesecker JM, Hatch AC. Ultraviolet radiation, toxic chemicals and amphibian population declines. Div Dist. (2003) 9:12340. doi: 10.1046/j.1472-4642.2003.00015.x

209. Van Meter RJ, Glinski DA, Hong T, Cyterski M, Henderson WM, Purucker ST. Estimating terrestrial amphibian pesticide body burden through dermal exposure. Environ Poll. (2014) 193:262-8. doi: 10.1016/j.envpol.2014.07.003

210. Simoncelli F, Belia S, Di Rosa I, Paracucchi R, Rossi R, La Porta G, et al. Short-term cadmium exposure induces stress responses in frog (Pelophylax bergeri) skin organ culture. Ecotox Environ Saf. (2015) 122:2219. doi: 10.1016/j.ecoenv.2015.08.001

211. Bellantuono V, Cassano G, Lippe C. Pesticides alter ion transport across frog (Pelophylax kl. esculentus) skin. Chem Ecol. (2014) 30:602-10. doi: $10.1080 / 02757540.2014 .917177$

212. Cassano G, Bellantuono V, Ardizzone C, Lippe C. Atrazine increases the sodium absorption in frog (Rana esculenta) skin. Environ Tox Chem. (2006) 25:509-13. doi: 10.1897/05-141R.1

213. De Jesús Andino F, Lawrence BP, Robert J. Long term effects of carbaryl exposure on antiviral immune responses in Xenopus laevis. Chemosphere (2017) 170:169-75. doi: 10.1016/j.chemosphere.2016.12.018

214. Sifkarovski J, Grayfer L, De Jesus Andino F, Lawrence BP, Robert J. Negative effects of low dose atrazine exposure on the development of effective immunity to FV3 in Xenopus laevis. Dev Comp Immunol. (2014) 47:52-8. doi: 10.1016/j.dci.2014.06.012

215. Pochini KM, Hoverman JT. Reciprocal effects of pesticides and pathogens on amphibian hosts: The importance of exposure order and timing. Environ Pollut. (2017) 221:359-66. doi: 10.1016/j.envpol.2016.11.086

216. Schadich E, Cole ALJ, Mason D, Squire M. Effect of the pesticide carbaryl on the production of skin peptides of Litoria raniformis frogs. Austral J Ecotox. (2009) 15:17-24.

217. Novales Flamarique I, Ovaska K, Davis TM. UV-B induced damage to the skin and ocular system of amphibians. Biol Bull. (2000) 199:187-8. doi: $10.2307 / 1542889$

218. Cramp RL, Franklin CE. Exploring the link between ultraviolet B radiation and immune function in amphibians: Implications for emerging infectious diseases. Cons Physiol. (2018) 6:coy035. doi: 10.1093/conphys/coy035

219. Yu S, Wages M, Willming M, Cobb GP, Maul JD. Joint effects of pesticides and ultraviolet-B radiation on amphibian larvae. Environ Pollut. (2015) 207:248-55. doi: 10.1016/j.envpol.2015.09.029

220. Biniek K, Levi K, Dauskardt RH. Solar UV radiation reduces the barrier function of human skin. PNAS (2012) 109:17111-6. doi: 10.1073/pnas.1206851109

221. Abedi S, Sharifpour I, Mozanzadeh MT, Zorriehzahra J, Khodabandeh S, Gisbert E. A histological and ultrastructural study of the skin of rainbow trout (Oncorhynchus mykiss) alevins exposed to different levels of ultraviolet B radiation. I Photochem Photobiol. (2015) 147:56-62. doi: 10.1016/j.jphotobiol.2015.02.021

222. Brunner JL, Schock DM, Collins JP. Transmission dynamics of the amphibian ranavirus Ambystoma tigrinum virus. Dis Aquatic Org. (2007) 77:87-95. doi: 10.3354/dao01845

223. Schock DM, Bollinger TK, Chinchar VG, Jancovich JK, Collins JP. Experimental evidence that amphibian ranaviruses are multi-host pathogens. Copeia (2008) 2008:133-43. doi: 10.1643/CP-06-134

224. Grayfer L, Andino FDJ, Chen G, Chinchar GV, Robert J. Immune evasion strategies of ranaviruses and innate immune responses to these emerging pathogens. Viruses (2012) 4:1075-92. doi: 10.3390/v4071075

225. Robert J, Abramowitz L, Gantress J, Morales HD. Xenopus laevis: a possible vector of Ranavirus infection? J Wildlife Dis. (2007) 43:645-52. doi: 10.7589/0090-3558-43.4.645

226. Robert J, Morales H, Buck W, Cohen N, Marr S, Gantress J. Adaptive immunity and histopathology in frog virus 3-infected Xenopus. Virology (2005) 332:667-75. doi: 10.1016/j.virol.2004.12.012

227. Morales HD, Robert J. Characterization of primary and memory CD8 Tcell responses against ranavirus (FV3) in Xenopus laevis. J Virol. (2007) 81:2240-8. doi: 10.1128/JVI.01104-06

228. Morales HD, Abramowitz L, Gertz J, Sowa J, Vogel A, Robert J. Innate immune responses and permissiveness to ranavirus infection of peritoneal leukocytes in the frog Xenopus laevis. J Virol. (2010) 84:4912-22. doi: 10.1128/JVI.02486-09
229. Koubourli DV, Wendel ES, Yaparla A, Ghaul JR, Grayfer L. Immune roles of amphibian (Xenopus laevis) tadpole granulocytes during Frog Virus 3 ranavirus infections. Dev Comp Immunol. (2017) 72:112-8. doi: 10.1016/j.dci.2017.02.016

230. Robert J, George E, De Jesús Andino F, Chen G. Waterborne infectivity of the Ranavirus frog virus 3 in Xenopus laevis. Virology (2011) 417:410-7. doi: 10.1016/j.virol.2011.06.026

231. Gray MJ, Miller DL, Hoverman JT. Ecology and pathology of amphibian ranaviruses. Dis Aquatic Org. (2009) 87:243-66. doi: 10.3354/dao02138

232. Forzán MJ, Jones KM, Ariel E, Whittington RJ, Wood J, Markham RJF, et al. Pathogenesis of Frog Virus 3 (Ranavirus, Iridoviridae) Infection in Wood Frogs (Rana sylvatica). Vet Pathol. (2017) 54:531-48. doi: 10.1177/0300985816684929

233. Wendel ES, Yaparla A, Koubourli DV, Grayfer L. Amphibian (Xenopus laevis) tadpoles and adult frogs mount distinct interferon responses to the Frog Virus 3 ranavirus. Virology (2017) 503:12-20. doi: 10.1016/j.virol.2017.01.001

234. Berger L, Hyatt AD, Speare R, Longcore JE. Life cycle stages of the amphibian chytrid Batrachochytrium dendrobatidis. Dis Aquatic Org. (2005) 68:51-63. doi: $10.3354 /$ dao068051

235. Brutyn M, D'Herde K, Dhaenens M, Van Rooij P, Verbrugghe E, Hyatt $\mathrm{AD}$, et al. Batrachochytrium dendrobatidis zoospore secretions rapidly disturb intercellular junctions in frog skin. Fun Gen Biol. (2012) 49:830-7. doi: 10.1016/j.fgb.2012.07.002

236. Rosenblum EB, Poorten TJ, Settles M, Murdoch GK. Only skin deep: shared genetic response to the deadly chytrid fungus in susceptible frog species. Mol Ecol. (2012) 21:3110-20. doi: 10.1111/j.1365-294X.2012.05481.x

237. Zhang Z, Zhang B, Nie X, Liu Q, Xie F, Shang D. Transcriptome analysis and identification of genes related to immune function in skin of the Chinese brown frog. Zoo Sci. (2009) 26:80-6. doi: 10.2108/zsj.26.80

238. Savage AE, Kiemnec-Tyburczy KM, Ellison AR, Fleischer RC, Zamudio KR. Conservation and divergence in the frog immunome: pyrosequencing and de novo assembly of immune tissue transcriptomes. Gene (2014) 542:98-108. doi: 10.1016/j.gene.2014.03.051

239. Chen YE, Tsao H. The skin microbiome: current perspectives and future challenges. J Am Acad Derm. (2013) 69:143-55. doi: 10.1016/j.jaad.2013.01.016

240. Fitzpatrick BM, Allison AL. Similarity and differentiation between bacteria associated with skin of salamanders (Plethodon jordani) and free-living assemblages. FEMS Micro Ecol. (2014) 88:482-94. doi: 10.1111/1574-6941.12314

241. Loudon AH, Holland JA, Umile TP, Burzynski EA, Minbiole KP, Harris RN. Interactions between amphibians' symbiotic bacteria cause the production of emergent anti-fungal metabolites. Front Microbiol. (2014) 5:441. doi: $10.3389 /$ fmicb.2014.00441

242. Kueneman JG, Woodhams DC, Harris R, Archer HM, Knight R, McKenzie VJ. Probiotic treatment restores protection against lethal fungal infection lost during amphibian captivity. Proc Biol Sci. (2016) 283:20161553. doi: 10.1098/rspb.2016.1553

243. Jani AJ, Briggs CJ. Host and aquatic environment shape the amphibian skin microbiome but effects on downstream resistance to the pathogen Batrachochytrium dendrobatidis Are Variable. Front Microbiol. (2018) 9:487. doi: 10.3389/fmicb.2018.00487

244. Rebollar EA, Simonetti SJ, Shoemaker WR, Harris RN. Direct and indirect horizontal transmission of the antifungal probiotic bacterium Janthinobacterium lividum on green frog (Lithobates clamitans) tadpoles. Environ Microbiol. (2016) 82:2457-66. doi: 10.1128/AEM.04 147-15

245. McKenzie VJ, Bowers RM, Fierer N, Knight R, Lauber CL. Co-habiting amphibian species harbour unique skin bacterial communities in wild populations. ISME J. (2012) 6:588-96. doi: 10.1038/ismej.2011.129

246. Gibb K, Schobben X, Christian K. Frogs host faecal bacteria typically associated with humans. Can J Micro. (2017) 63:633-7. doi: 10.1139/cjm-2017-0119

247. Bletz MC, Perl RGB, Vences M. Skin microbiota differs drastically between co-occurring frogs and newts. Royal Soc Open Sci. (2017) 4:170107. doi: 10.1098/rsos.170107

248. Muletz CR, Myers JM, Domangue RJ, Herrick JB, Harris RN. Soil bioaugmentation with amphibian cutaneous bacteria protects amphibian 
hosts from infection by Batrachochytrium dendrobatidis. Biol Cons. (2012) 152:119-26. doi: 10.1016/j.biocon.2012.03.022

249. Walke JB, Belden LK. Harnessing the microbiome to prevent fungal infections: lessons from amphibians. PLoS Path. (2016) 12:e1005796. doi: 10.1371/journal.ppat.1005796

250. Belden LK, Hughey MC, Rebollar EA, Umile TP, Loftus SC, Burzynski EA, et al. Panamanian frog species host unique skin bacterial communities. Front Micro. (2015) 6:1171. doi: 10.3389/fmicb.2015.01171

251. Walke JB, Becker MH, Hughy MC, Swartwout MC, Jensen RV, Belden LK. Most of the Dominant members of amphibian skin bacterial communities can be readily cultured. Appl Environ Microbiol. (2015) 81:6589-600. doi: 10.1128/AEM.01486-15

252. Rodrigues Hoffmann A. The cutaneous ecosystem: the roles of the skin microbiome in health and its association with inflammatory skin conditions in humans and animals. Vet Derm. (2017) 28:60-e15. doi: 10.1111/vde.12408

253. Longo AV, Savage AE, Hewson I, Zamudio KR. Seasonal and ontogenetic variation of skin microbial communities and relationships to natural disease dynamics in declining amphibians. Royal Soc Open Sci. (2015) 2:140377. doi: 10.1098/rsos.140377

254. Antwis RE, Haworth RL, Engelmoer DJ, Ogilvy V, Fidgett AL, Preziosi RF. Ex situ diet influences the bacterial community associated with the skin of red-eyed tree frogs (Agalychnis callidryas). PloS ONE (2014) 9:e85563. doi: 10.1371 /journal.pone. 0085563

255. Sabino-Pinto J, Bletz MC, Islam MM, Shimizu N, Bhuju S, Geffers R, et al. Composition of the cutaneous bacterial community in japanese amphibians: effects of captivity, host species, and body region. Micro Ecol. (2016) 72:4609. doi: 10.1007/s00248-016-0797-6

256. Kueneman JG, Parfrey LW, Woodhams DC, Archer HM, Knight $\mathrm{R}$, McKenzie VJ. The amphibian skin-associated microbiome across species, space and life history stages. Mol Ecol. (2014) 23:1238-50. doi: $10.1111 / \mathrm{mec} .12510$

257. Becker MH, Richards-Zawacki CL, Gratwicke B, Belden LK. The effect of captivity on the cutaneous bacterial community of the critically endangered Panamanian golden frog (Atelopus zeteki). Biol Cons. (2014) 176:199-206. doi: 10.1016/j.biocon.2014.05.029

258. Krynak KL, Burke DJ, Benard MF. Rodeo ${ }^{\mathrm{TM}}$ herbicide negatively affects blanchard's cricket frogs (Acris blanchardi) survival and alters the skin-associated bacterial community. J Herp. (2017) 51:402-10. doi: 10.1670/16-092

259. McCoy KA, Peralta AL. Pesticides Could alter amphibian skin microbiomes and the effects of Batrachochytrium dendrobatidis. Front Micro. (2018) 9:748. doi: $10.3389 /$ fmicb.2018.00748

260. Rohr JR, Brown J, Battaglin WA, McMahon TA, Relyea RA. A pesticide paradox: fungicides indirectly increase fungal infections. Ecol Appl. (2017) 27:2290-302. doi: 10.1002/eap.1607

261. Madison JD, Berg EA, Abarca JG, Whitfield SM, Gorbatenko O, Pinto A, et al. Characterization of Batrachochytrium dendrobatidis inhibiting bacteria from amphibian populations in costa Rica. Front Micro. (2017) 8:290. doi: $10.3389 /$ fmicb.2017.00290

262. Woodhams DC, Vredenburg VT, Simon M-A, Billheimer D, Shakhtour B, Shyr Y, et al. Symbiotic bacteria contribute to innate immune defences of the threatened mountain yellow-legged frog, Rana muscosa. Biol Cons. (2007) 138:390-8. doi: 10.1016/j.biocon.2007.05.004

263. Woodhams DC, Alford RA, Antwis RE, Archer H, Becker MH, Belden LK, et al. Antifungal isolates database of amphibian skin-associated bacteria and function against emerging fungal pathogens. Ecology (2015) 96:595. doi: $10.1890 / 14-1837.1$

264. Myers JM, Ramsey JP, Blackman AL, Nichols AE, Minbole KP, Harris RN. Synergistic inhibition of the lethal fungal pathogen Batrachochytrium dendrobatidis: the combined effect of symbiotic bacterial metabolites and antimicrobial peptides of the frog Rana muscosa. J Chem Ecol. (2012) 38:958-65. doi: 10.1007/s10886-012-0170-2

Conflict of Interest Statement: The authors declare that the research was conducted in the absence of any commercial or financial relationships that could be construed as a potential conflict of interest.

Copyright $\odot 2019$ Varga, Bui-Marinos and Katzenback. This is an open-access article distributed under the terms of the Creative Commons Attribution License (CC BY). The use, distribution or reproduction in other forums is permitted, provided the original author(s) and the copyright owner(s) are credited and that the original publication in this journal is cited, in accordance with accepted academic practice. No use, distribution or reproduction is permitted which does not comply with these terms. 